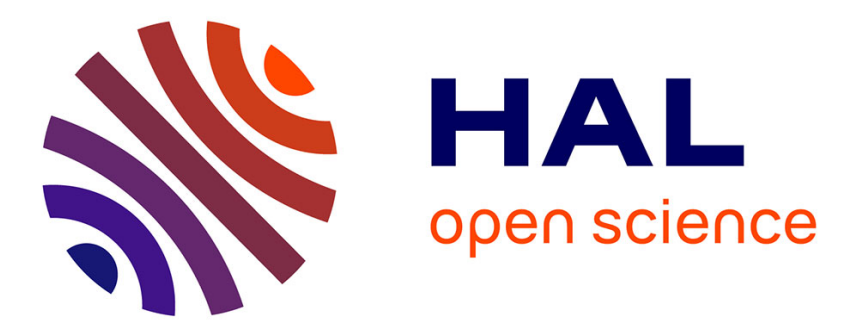

\title{
How can aroma-related cross-modal interactions be analysed? A review of current methodologies
}

Pauline Poinot, Gaëlle Arvisenet, Jérôme Ledauphin, Jean-Luc Gaillard, Carole Prost

\section{- To cite this version:}

Pauline Poinot, Gaëlle Arvisenet, Jérôme Ledauphin, Jean-Luc Gaillard, Carole Prost. How can aroma-related cross-modal interactions be analysed? A review of current methodologies. Food Quality and Preference, 2013, 28 (1), pp.304-316. 10.1016/j.foodqual.2012.10.007 . hal-01184832

\section{HAL Id: hal-01184832 \\ https://hal.science/hal-01184832}

Submitted on 17 Aug 2015

HAL is a multi-disciplinary open access archive for the deposit and dissemination of scientific research documents, whether they are published or not. The documents may come from teaching and research institutions in France or abroad, or from public or private research centers.
L'archive ouverte pluridisciplinaire HAL, est destinée au dépôt et à la diffusion de documents scientifiques de niveau recherche, publiés ou non, émanant des établissements d'enseignement et de recherche français ou étrangers, des laboratoires publics ou privés. 


\title{
How can aroma-related cross-modal interactions be analysed? A review of current methodologies
}

\author{
Pauline Poinot $^{\mathrm{a}, *}$, Gaëlle Arvisenet ${ }^{\mathrm{b}}$, Jérôme Ledauphin ${ }^{\mathrm{a}}$, Jean-Luc Gaillard ${ }^{\mathrm{a}}$, Carole Prost ${ }^{\mathrm{b}}$ \\ ${ }^{a}$ Caen University, UR ABTE 4651 - IFR 146 ICORE, Campus 2, Sciences 2, Caen, France \\ ${ }^{\mathrm{b}}$ PRESS LUNAM, ONIRIS, UMR GEPEA CNRS 6144, Food Aroma Research Group, Nantes, France
}

\section{A R T I C L E I N F O}

\section{Article history:}

Received 1 June 2012

Received in revised form 21 October 2012

Accepted 22 October 2012

Available online 30 October 2012

\section{Keywords:}

Cross-modal interaction

Aroma

Volatile compound

Sensory analysis

Instrumental method

\begin{abstract}
A B S T R A C T
Understanding the mechanisms involved in the perception of food aroma is one of the major objectives of flavour studies. Yet, it remains difficult to explain this perception due to the diversity of cross-modal interactions that occur between aroma, taste and texture during food consumption. Various sensory and instrumental methods have been developed to describe such interactions and to highlight their origins. Each of them has its own advantages and drawbacks. This paper describes the methods used over the past decade in order to help researchers choose the right approach to study aroma-related interactions. Their objectives, weaknesses and strengths are reported and contrasted. Their ability to reveal interactions in model and real food matrices is also discussed. Finally, innovative original approaches are presented.
\end{abstract}

(c) 2012 Elsevier Ltd. All rights reserved.

\section{Contents}

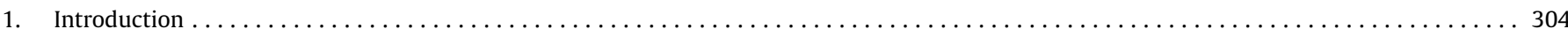

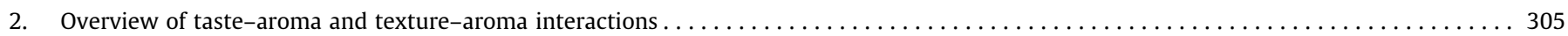

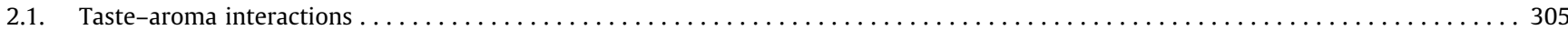

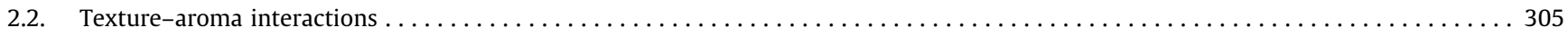

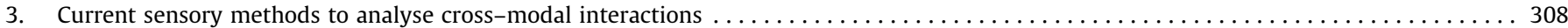

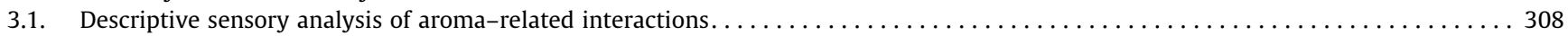

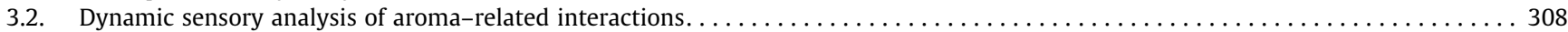

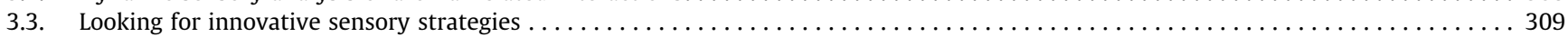

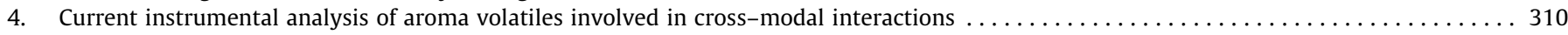

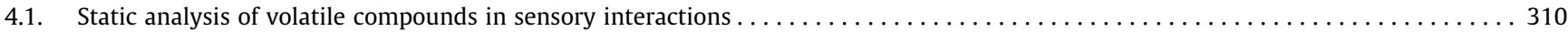

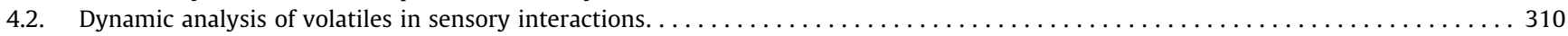

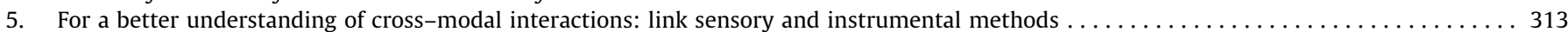

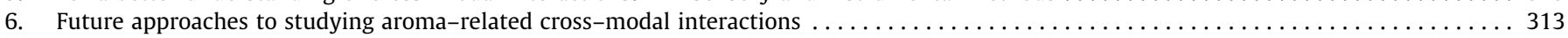

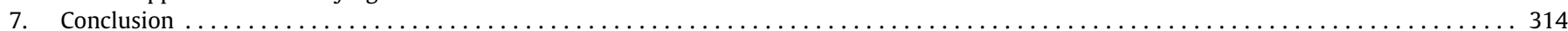

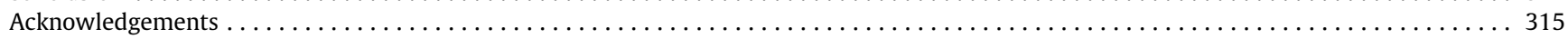

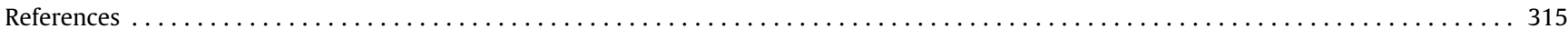

\section{Introduction}

While many studies have dealt with the factors that influence flavour perception, the sensory response remains difficult to

\footnotetext{
* Corresponding author. Tel.: +33 2315674 91; fax: +33231567303.

E-mail addresses: pauline.poinot@unicaen.fr (P. Poinot), gaelle.arvisenet@onirisnantes.fr (G. Arvisenet), jerome.ledauphin@unicaen.fr (J. Ledauphin), jean-luc.gaillard@unicaen.fr (J.-L. Gaillard), carole.prost@oniris-nantes.fr (C. Prost).
}

interpret due to the multi-faceted interactions between aroma, taste and texture stimuli (Auvray \& Spence, 2008; Buettner \& Beauchamp, 2010; Delwiche, 2004; Noble, 1996; Rolls, 2005). In fact, the perception of one of these stimuli can be affected by the perception of another one which is assessed by a different sense.

Full descriptions of aroma-related interactions have already been reported in excellent reviews (e.g. Auvray \& Spence, 2008; Buettner \& Beauchamp, 2010; Delwiche, 2004; Noble, 1996). These focused on the fundamental mechanisms involved in the 
appearance of such interactions. Surprisingly, however, the practical methods used to identify aroma-related interactions have not yet been reviewed. Such a review would be very useful for researchers in order to help them select the most appropriate method according to the study they plan to undertake. For this purpose, this review describes and compares these different methods with the aim of providing a new tool for aroma-related interaction studies. Special attention will be paid to the methods which enable taste-aroma and texture-aroma interactions to be explored. Their advantages and drawbacks will be presented and contrasted. Their practical application to real food matrices will also be discussed. Finally, innovative methods to study interactions involving complex aromas will be presented.

\section{Overview of taste-aroma and texture-aroma interactions}

In the following paragraphs, recent findings on taste-aroma and texture-aroma interactions will be briefly introduced, with a focus on the effect of retronasal aroma perception on taste and texture (and vice versa). However, it should be kept in mind that an orthonasal odorant stimulus could also lead to interactions with taste and texture stimuli. Previous studies have already compared the influence of either orthonasal perception or retronasal perception on cross-modal interactions (e.g. Welge-Lüssen, Husner, Wolfensberger, \& Hummel, 2009). The authors revealed that concomitant taste stimuli had a different impact on orthonasal and retronasal olfaction. They showed that the application of a sweet taste significantly enhanced the processing of a 'vanilla' stimulus when it was specifically presented through the retronasal route. Moreover, when the taste and the odorant stimuli were not consciously associated, the information was processed less easily when the odorant stimulus was presented through the orthonasal route. Thus, ortho- and retronasal perceptions are processed differently and various interactions may occur with each of these perceptions (Hummel \& Heilmann, 2008; Welge-Lüssen et al., 2009).

\subsection{Taste-aroma interactions}

Among cross-modal interactions, those of taste-aroma have been widely studied. Overall, they can occur when taste and aroma compounds are at supra- or subthreshold concentrations, and depend on the food matrix studied (Labbe \& Martin, 2009; Labbe, Rytz, Morgenegg, Ali, \& Martin, 2007; Lethuaut et al., 2005; Marks, Shepard, Burger, \& Chakwin, 2012).

Considering the effect of aroma on taste perception, it has been shown that aroma can have diverse effects on taste perception. For example, Boakes and Hemberger (2012) demonstrated an aroma could mask the perception of a taste (e.g. a 'caramel' aroma has masked sourness). In other cases, aroma did not interfere with taste intensity (e.g. 'apple' notes did not influence sweetness perception; Lethuaut et al., 2005). Lastly, aroma can increase the perception of taste: (1) 'vanilla' 'caramel' or various 'fruity' notes increased sweetness (Boakes \& Hemberger, 2012; Burseg, Camacho, Knoop, \& Bult, 2010; Labbe, Damevin, Vaccher, Morgenegg, \& Martin, 2006; Tournier et al., 2009), (2) 'cocoa' notes boosted bitterness (Labbe et al., 2006), and (3) 'meat', 'fish', and 'cheese' notes enhanced saltiness (Lawrence, Salles, Septier, Busch, \& ThomasDanguin, 2009; Nasri, Beno, Septier, Salles, \& Thomas-Danguin, 2011).

Regarding the effect of taste on aroma perception, variable effects have also been highlighted. Among them can be cited: (1) an increase in the intensity of different 'fruity' aromas by sweetness (Hort \& Hollowood, 2004; Lethuaut, Weel, Boelrijk, \& Brossard, 2004; Tournier et al., 2009), (2) an enhancement of 'mushroom' aroma intensity by saltiness (Ventanas, Mustonen, Puolanne, \& Tuorila, 2010a; Ventanas, Puolanne, \& Tuorila, 2010 b), and (3) a rise in 'lemon' aroma intensity by sourness (Hewson, Hollowood, Chandra, \& Hort, 2008).

More surprising results have also been obtained. For instance, Boakes and Hemberger (2012) revealed that a citral aroma decreased the sourness of solutions while it increased their sweetness. In addition, Marks et al. (2012) and Hewson et al. (2008) highlighted an additive effect of sweet components with citral and/or limonene volatiles having a 'citrus'-like aroma.

Overall, this data divergence stresses the diversity that characterises these interactions, which are due to unpredictable physicochemical, physiological and psychological mechanisms. Physicochemical mechanisms include, for instance, chemical and physical interactions between taste components and volatile compounds. The presence of some taste compounds within a matrix may affect the partition of some volatiles, their molar concentration and the water activity coefficient. This results in a decrease, an increase or a constant concentration of volatiles in the headspace (e.g. Saint-Eve, Lauverjat, Magnan, Déléris, \& Souchon, 2009). Moreover, the addition of a taste compound could, in some cases, lead to a change in the matrix structure (Heenan et al., 2012; Hewson et al., 2008; Siefarth et al., 2011). The diffusion of volatiles through the matrix is then affected, impacting their release into the headspace. An illustration of physico-chemical mechanisms is the well-known "salting-out" phenomenon, in which salt causes the release of volatiles (Saint-Eve et al., 2009; Ventanas et al., 2010a, 2010b).

Modification of the matrix structure could also trigger a change in the physiological mechanisms involved in food breakdown in the mouth. Clearly, individual oral physiology, such as salivation, temperature, mucosa, chewing force and swallowing, could vary with matrix structure (Buettner \& Beauchamp, 2010; Noble, 1996).

Although aroma and taste are perceived by separate physiological routes, many authors have reported that psychological mechanisms must also be considered to explain why the intensity of a taste may be modified by aroma perception, and vice versa (e.g. Stevenson, Prescott, \& Boakes, 1999). Congruency, which is defined as "the extent to which two stimuli are appropriate for combination in a food product", between taste and aroma was suggested by Schifferstein and Verlegh (1996) as an important criterion to consider. This phenomenon is based on associations formed during previous encounters with specific complex stimuli, which explains why it would be culturally determined (Murphy \& Cain, 1980). As reported by Noble (1996), taste and aroma stimuli interact most strongly when the associations are congruent, as is true for the interaction of fruitiness with sweetness or sourness (e.g. the perceived intensity of an almond aroma increased when sucrose level increased; Tournier et al., 2009).

To date, taste-aroma interactions have mostly been analysed in model matrices, generally liquid or semi-solid (Table 1 ). These matrices were formulated under controlled conditions, containing a precise amount of volatile and taste compounds. Only a few works have dealt with sensory interactions in real food products (i.e. Poinot et al., 2011). This underlines the high degree of difficulty which characterises the study of interactions when complex stimuli are involved.

\subsection{Texture-aroma interactions}

Texture-aroma interactions have also been studied mainly in model or slightly complex matrices, which in most cases had a semi-solid or gel form. Once again, they were obtained by adding various amounts of structuring and aroma compounds in a stringently controlled fashion. 
Table 1

Sensory methodologies followed to analyse aroma-related interactions.

\begin{tabular}{|c|c|c|c|c|c|c|c|c|}
\hline Sensory test & $\begin{array}{l}\text { Products/ } \\
\text { stimuli } \\
\text { evaluated }\end{array}$ & $\begin{array}{l}\text { Number of } \\
\text { different } \\
\text { products/ } \\
\text { stimuli } \\
\text { evaluated }\end{array}$ & Assessors & $\begin{array}{l}\text { Attributes: } \\
\text { number }\end{array}$ & Scoring & Tasting protocol & $\begin{array}{l}\text { Sessions } \\
\text { replicated } \\
\text { X times }\end{array}$ & References \\
\hline \multirow{16}{*}{$\begin{array}{c}\text { Descriptive } \\
\text { sensory } \\
\text { analysis }\end{array}$} & $\begin{array}{l}\text { Model } \\
\text { emulsions }\end{array}$ & 6 & 10 trained & $\begin{array}{l}\text { Od, Ar, Tas, } \\
\text { Tex: } 14\end{array}$ & $\begin{array}{l}\text { Nonstructured } \\
10 \mathrm{~cm} \text { scale }\end{array}$ & * & 2 & $\begin{array}{l}\text { Arancibia et al. } \\
\text { (2011) }\end{array}$ \\
\hline & Gelatine gels & 18 & 16 trained & Ar: 1 & $\begin{array}{l}\text { Ten point } \\
\text { structured } \\
\text { scale }\end{array}$ & * & * & $\begin{array}{l}\text { Baek et al. } \\
\text { (1999) }\end{array}$ \\
\hline & Solutions & 12 & 15 trained & Tas: 4 & $\begin{array}{l}\text { Twenty-one- } \\
\text { point scale }\end{array}$ & * & 4 & $\begin{array}{l}\text { Boakes and } \\
\text { Hemberger } \\
(2012)\end{array}$ \\
\hline & $\begin{array}{l}\text { Gelatine and } \\
\text { pectin gels }\end{array}$ & 6 & 12 trained & $\begin{array}{l}\text { Od, Ar, Tas, } \\
\text { Tex: } 4\end{array}$ & $\begin{array}{l}\text { Magnitude } \\
\text { estimation } \\
\text { scale }\end{array}$ & No & 3 & $\begin{array}{l}\text { Boland et al. } \\
(2006)\end{array}$ \\
\hline & $\begin{array}{l}\text { Model } \\
\text { candies }\end{array}$ & 4 & 12 trained & $\begin{array}{l}\text { Ar, Tas, } \\
\text { Tex: } 14\end{array}$ & $\begin{array}{l}\text { Nonstructured } \\
\text { scale }\end{array}$ & Yes & 2 & $\begin{array}{l}\text { Déléris et al. } \\
\text { (2011) and } \\
\text { Saint-Eve et al. } \\
\text { (2011) }\end{array}$ \\
\hline & Starch pastes & 20 & 14 trained & $\begin{array}{l}\text { Ar, Tas, } \\
\text { Tex: } 3\end{array}$ & $\begin{array}{l}\text { Magnitude } \\
\text { estimation } \\
\text { scale }\end{array}$ & ${ }^{*}$ & 2 & $\begin{array}{l}\text { Ferry et al. } \\
(2006)\end{array}$ \\
\hline & Milk gels & 3 & 13 trained & $\begin{array}{l}\text { Ar, Tas, } \\
\text { Tex: } 9\end{array}$ & $\begin{array}{l}\text { Nonstructured } \\
\text { scale }\end{array}$ & Yes & 3 & $\begin{array}{l}\text { Gierczynski } \\
\text { et al. (2008) }\end{array}$ \\
\hline & Solutions & 64 & 10 trained & Ar, Tas: 3 & $\begin{array}{l}\text { Magnitude } \\
\text { estimation } \\
\text { scale }\end{array}$ & * & 2 & $\begin{array}{l}\text { Hewson et al. } \\
\text { (2008) }\end{array}$ \\
\hline & Solutions & 8 and 108 & 13 trained & Ar, Tas: 3 & $\begin{array}{l}\text { Magnitude } \\
\text { estimation } \\
\text { scale }\end{array}$ & Yes & 2 & $\begin{array}{l}\text { Hollowood } \\
\text { et al. (2002) }\end{array}$ \\
\hline & $\begin{array}{l}\text { Model dairy } \\
\text { desserts }\end{array}$ & 27 & 19 trained & $\begin{array}{l}\text { Ar, Tas, } \\
\text { Tex: } 8\end{array}$ & $\begin{array}{l}\text { Magnitude } \\
\text { labelled scale }\end{array}$ & * & $\begin{array}{l}1 \text { product } \\
\text { replicated } \\
(9)\end{array}$ & $\begin{array}{l}\text { Lethuaut et al. } \\
\text { (2005) }\end{array}$ \\
\hline & Protein gels & 2 & 7 trained & Ar: 1 & $\begin{array}{l}\text { Seven-point } \\
\text { scale }\end{array}$ & Yes & 3 & $\begin{array}{l}\text { Mestres et al. } \\
(2005)\end{array}$ \\
\hline & $\begin{array}{l}\text { Commercial } \\
\text { and } \\
\text { reconstituted } \\
\text { wines }\end{array}$ & 24 & 30 trained & Ar, Tas: 7 & $\begin{array}{l}\text { Ten or nine- } \\
\text { point scale }\end{array}$ & * & 2 & $\begin{array}{l}\text { Sáenz-Navajas } \\
\text { et al. (2010) }\end{array}$ \\
\hline & Yogurts & 24 & 16 trained & $\begin{array}{l}\text { Ar, Tas, } \\
\text { Tex: } 17\end{array}$ & $\begin{array}{l}\text { Nonstructured } \\
\text { scale }\end{array}$ & $*$ & 2 & $\begin{array}{l}\text { Saint-Eve et al. } \\
\text { (2004) }\end{array}$ \\
\hline & $\begin{array}{l}\text { Model } \\
\text { cheeses }\end{array}$ & 10 & 10 trained & $\begin{array}{l}\text { Ar, Tas, } \\
\text { Tex: } 17\end{array}$ & $\begin{array}{l}\text { Nonstructured } \\
\text { scale }\end{array}$ & Yes & 2 & $\begin{array}{l}\text { Saint-Eve et al. } \\
\text { (2009) }\end{array}$ \\
\hline & $\begin{array}{l}\text { Beef broth } \\
\text { model } \\
\text { systems }\end{array}$ & 16 & 8 trained & $\begin{array}{l}\text { Od, Ar, Tas: } \\
11\end{array}$ & $\begin{array}{l}\text { Nonstructured } \\
10 \mathrm{~cm} \text { scale }\end{array}$ & Yes & 2 & $\begin{array}{l}\text { Ventanas et al., } \\
\text { 2010a }\end{array}$ \\
\hline & $\begin{array}{l}\text { Cooked } \\
\text { bologna type } \\
\text { sausages }\end{array}$ & 9 & 8 trained & $\begin{array}{l}\text { Od, Ar, Tas, } \\
\text { Tex: } 12\end{array}$ & $\begin{array}{l}\text { Nonstructured } \\
10 \mathrm{~cm} \text { scale }\end{array}$ & * & 2 & $\begin{array}{l}\text { Ventanas et al. } \\
\text { (2010b) }\end{array}$ \\
\hline \multirow{8}{*}{$\begin{array}{l}\text { Rating task: } \\
\text { sensory profile } \\
\text { with non } \\
\text { trained } \\
\text { panellists }\end{array}$} & Solutions & 12 & 17 naïve & Tas: 4 & $\begin{array}{l}\text { Twenty-one- } \\
\text { point scale }\end{array}$ & * & 4 & $\begin{array}{l}\text { Boakes and } \\
\text { Hemberger } \\
(2012)\end{array}$ \\
\hline & Milk products & 7 & $\begin{array}{l}11 \\
\text { experienced }\end{array}$ & Ar, Tex: 3 & $\begin{array}{l}\text { Nonstructured } \\
13 \mathrm{~cm} \text { scale }\end{array}$ & Yes & Yes & $\begin{array}{l}\text { Bult et al. } \\
\text { (2007) }\end{array}$ \\
\hline & Solutions & 20 & 59 naïve & $\begin{array}{l}\text { Od, Ar, Tas: } \\
5\end{array}$ & $\begin{array}{l}\text { Nonstructured } \\
10 \mathrm{~cm} \text { scale }\end{array}$ & Yes & * & $\begin{array}{l}\text { Lawrence et al. } \\
\text { (2009) }\end{array}$ \\
\hline & $\begin{array}{l}\text { Model } \\
\text { cheeses }\end{array}$ & 16 & 27 naïve & $\begin{array}{l}\text { Od, Ar, Tas, } \\
\text { Tex: } 8\end{array}$ & $\begin{array}{l}\text { Nonstructured } \\
10 \mathrm{~cm} \text { scale }\end{array}$ & With or without nose clips & ${ }^{*}$ & $\begin{array}{l}\text { Lawrence et al. } \\
\text { (2011) }\end{array}$ \\
\hline & Solutions & 22 & $16 * 4$ naïve & Ar, Tas: 1 & $\begin{array}{l}\text { Labelled } \\
\text { magnitude } \\
\text { scale }\end{array}$ & Yes & 5 & $\begin{array}{l}\text { Marks et al. } \\
(2012)\end{array}$ \\
\hline & Solutions & 12 & 64 naïve & Ar, Tas: 5 & $\begin{array}{l}\text { Nonstructured } \\
10 \mathrm{~cm} \text { scale }\end{array}$ & * & * & $\begin{array}{l}\text { Nasri et al. } \\
\text { (2011) }\end{array}$ \\
\hline & Milk products & 6 & 18 naïve & Ar, Tex:2 & $\begin{array}{l}\text { Visual analog } \\
\text { scale }\end{array}$ & Yes & * & $\begin{array}{l}\text { Roudnitzky } \\
\text { et al. (2011) }\end{array}$ \\
\hline & $\begin{array}{l}\text { Model } \\
\text { custard } \\
\text { desserts }\end{array}$ & 16 & $\begin{array}{l}\text { From } 15 \text { to } \\
32 \text { naïve }\end{array}$ & $\begin{array}{l}\text { Ar, Tas, } \\
\text { Tex: } 5\end{array}$ & $\begin{array}{l}\text { Nonstructured } \\
13 \mathrm{~cm} \text { scale }\end{array}$ & With or without nose clips & 2 & $\begin{array}{l}\text { Tournier et al. } \\
\text { (2009) }\end{array}$ \\
\hline \multirow[t]{2}{*}{ Time-Intensity } & Gelatine gels & 5 & 11 trained & Ar: 1 & * & No & * & $\begin{array}{l}\text { Baek et al. } \\
\text { (1999) }\end{array}$ \\
\hline & Solutions & 8 & $\begin{array}{l}15 \text { naïve } \\
\text { and } \\
\text { experienced }\end{array}$ & Tas: 1 & $\begin{array}{l}\text { Time-intensity } \\
\text { scale } 0-100\end{array}$ & ${ }^{*}$ & 4 & $\begin{array}{l}\text { Burseg et al. } \\
(2010)\end{array}$ \\
\hline
\end{tabular}


Table 1 (continued)

\begin{tabular}{|c|c|c|c|c|c|c|c|c|}
\hline Sensory test & $\begin{array}{l}\text { Products/ } \\
\text { stimuli } \\
\text { evaluated }\end{array}$ & $\begin{array}{l}\text { Number of } \\
\text { different } \\
\text { products/ } \\
\text { stimuli } \\
\text { evaluated }\end{array}$ & Assessors & $\begin{array}{l}\text { Attributes: } \\
\text { number }\end{array}$ & Scoring & Tasting protocol & $\begin{array}{l}\text { Sessions } \\
\text { replicated } \\
\text { X times }\end{array}$ & References \\
\hline & Solutions & 3 & $\begin{array}{l}54 \text { naïve } \\
\text { and } \\
\text { experienced }\end{array}$ & Ar: 1 & $\begin{array}{l}\text { Structured } \\
\text { scale }\end{array}$ & No & 2 & $\begin{array}{l}\text { Hort and } \\
\text { Hollowood } \\
(2004)\end{array}$ \\
\hline & $\begin{array}{l}\text { Model dairy } \\
\text { desserts }\end{array}$ & 6 & $\begin{array}{l}7 \\
\text { experienced }\end{array}$ & Ar, Tas: 2 & $\begin{array}{l}\text { Nonstructured } \\
10 \text { point scale }\end{array}$ & Yes & 6 & $\begin{array}{l}\text { Lethuaut et al. } \\
\text { (2004) }\end{array}$ \\
\hline & Protein gels & 2 & $\begin{array}{l}7 \\
\text { experienced }\end{array}$ & Ar: 1 & No scale & Yes & 3 & $\begin{array}{l}\text { Mestres et al. } \\
(2006)\end{array}$ \\
\hline & $\begin{array}{l}\text { Cooked } \\
\text { bologna type } \\
\text { sausages }\end{array}$ & 4 & 8 trained & $\begin{array}{l}\text { Ar, Tas, } \\
\text { Tex: } 3\end{array}$ & $\begin{array}{l}\text { Nonstructured } \\
10 \mathrm{~cm} \text { scale }\end{array}$ & Yes & 3 & $\begin{array}{l}\text { Ventanas et al. } \\
\text { (2010b) }\end{array}$ \\
\hline & $\begin{array}{l}\text { Whey protein } \\
\text { gels }\end{array}$ & 10 & $\begin{array}{l}10 \\
\text { experienced }\end{array}$ & Ar: 2 & $\begin{array}{l}\text { Structured } \\
\text { scale }\end{array}$ & Yes & 3 & $\begin{array}{l}\text { Weel et al. } \\
(2002)\end{array}$ \\
\hline $\begin{array}{l}\text { Temporal } \\
\text { dominance of } \\
\text { sensations }\end{array}$ & $\begin{array}{l}\text { Model } \\
\text { candies }\end{array}$ & 4 & $\begin{array}{l}12 \\
\text { experienced }\end{array}$ & Ar, Tas: 6 & $\begin{array}{l}\text { Nonstructured } \\
10 \mathrm{~cm} \text { scale }\end{array}$ & Yes & 2 & $\begin{array}{l}\text { Déléris et al. } \\
\text { (2011) and } \\
\text { Saint-Eve et al. } \\
\text { (2011) }\end{array}$ \\
\hline $\begin{array}{r}\text { Free choice } \\
\text { profiling }\end{array}$ & Yogurts & 12 & $\begin{array}{l}16 \\
\text { experienced }\end{array}$ & Ar, Tas, Tex & $\begin{array}{l}\text { Nonstructured } \\
\text { scale }\end{array}$ & * & * & $\begin{array}{l}\text { Saint-Eve et al. } \\
(2004)\end{array}$ \\
\hline Ranking task & $\begin{array}{l}\text { Commercial } \\
\text { beverages }\end{array}$ & 12 & 10 naïve & $\begin{array}{l}\text { Od, Ar, Tas, } \\
\text { Tex: } 6\end{array}$ & $\begin{array}{l}\text { Nine point } \\
\text { structured } \\
\text { scale }\end{array}$ & With or without nose clips & 2 & $\begin{array}{l}\text { Labbe et al. } \\
\text { (2006) }\end{array}$ \\
\hline \multirow[t]{3}{*}{ Sorting task } & Apples & 5 & 30 naïve & $\begin{array}{l}\text { Od, Ar, Tas, } \\
\text { Tex }\end{array}$ & & $\begin{array}{l}\text { With or without masking } \\
\text { agents: nose clips, malic acid, } \\
\text { flavourless hard chewing } \\
\text { gum }\end{array}$ & $\begin{array}{l}1 \text { sample } \\
\text { duplicated }\end{array}$ & $\begin{array}{l}\text { Poinot et al. } \\
\text { (2011) }\end{array}$ \\
\hline & $\begin{array}{l}\text { Commercial } \\
\text { and } \\
\text { reconstituted } \\
\text { wines }\end{array}$ & 14 & $\begin{array}{l}35 \text { and } 30 \\
\text { experienced }\end{array}$ & Od, Ar, Ta & & $\begin{array}{l}\text { With or without nose clips/ } \\
\text { With or without glass lid }\end{array}$ & ${ }^{*}$ & $\begin{array}{l}\text { Saenz-Navajas } \\
(2012)\end{array}$ \\
\hline & Yogurts & 6 and 12 & 16 naïve & Tex & & * & 2 & $\begin{array}{l}\text { Saint-Eve et al. } \\
\text { (2004) }\end{array}$ \\
\hline
\end{tabular}

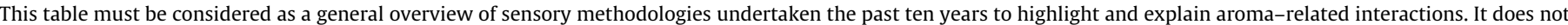
claim to list all sensory studies performed on aroma-related interactions.

Information not provided; Od: Odour attributes; Ar: Aroma attributes; Tas: Taste attributes; Tex: Texture attributes.

When regarding the impact of aroma on texture perception, aroma has been shown to change texture perception in some works For instance, Bult, de Wijk, and Hummel (2007) revealed that the presence of a 'cream' aroma was likely to raise the perceived thickness and creaminess of the studied products. In addition, Saint-Eve, Paci Kora, and Martin (2004), and Saint-Eve et al. (2009) showed that model cheeses and stirred yogurts with fatty notes were judged to be thicker than those without these notes.

Concerning the effect of texture on aroma perception, it has been shown that increasing the viscosity of liquid systems or the hardness of gel-like systems tends to reduce the intensity of their aroma (Baek, Linforth, Blake, \& Taylor, 1999; Boland, Delahunty, \& van Ruth, 2006; Bult et al. 2007; Ferry et al., 2006; Gierczynski, Laboure, \& Guichard, 2008; Hollowood, Linforth, \& Taylor, 2002; Juteau, Tournier, \& Guichard, 2004; Lethuaut et al., 2004; Lethuaut et al., 2005; Mestres, Moran, Jordan, \& Buettner, 2005; Saint-Eve et al., 2011; Weel et al., 2002). In other cases, a structuring agent had no effect on aroma intensity (González-Tomás, Bayarri, Taylor, \& Costell, 2007; Lethuaut et al., 2005; Tournier et al., 2009).

To explain these cross-modal interactions, physico-chemical, physiological and psychological mechanisms must be considered. Concerning physico-chemical mechanisms, it has been shown that some structuring agents may interact directly with volatile compounds leading to their retention in the food matrix. This is notably the case for whole milk proteins, fat, various proteins like gelatine, and some hydrocolloids, such as pectin or carboxymethylcellulose (Arancibia, Jublot, Costell, \& Bayarri, 2011; Arvisenet, Le Bail, Voilley, \& Cayot, 2002; Boland et al., 2006; González-Tomás et al.,
2007; Hansson, Giannouli, \& Van Ruth, 2003; Saint-Eve et al., 2009; Zafeiropoulou, Evageliou, Gardeli, Yanniotis, \& Komaitis, 2012). Starch was also shown to interact directly with some volatiles, provoking either their retention or their release due to a "salting-out” effect (Arancibia et al., 2011; González-Tomás et al., 2007; Keršienè, Adams, Dubra, De Kimpe, \& Leskauskaitè, 2008). These physico-chemical interactions depend on the matrix, the volatile compound and the structuring agent. Thus, in other studies, no or minor physico-chemical interactions between aroma and structuring compounds were revealed (e.g. whey protein, gelatine, starch, pectin, carrageenan, hydroxypropylmethyl cellulose) (Baek, et al., 1999; Déléris et al., 2011; González-Tomás et al., 2007; Hollowood et al., 2002; Lethuaut et al., 2004; Lethuaut et al., 2005; Mei, Reineccius, Knighton, \& Grimsrud, 2004; Weel et al., 2002).

Changing the physical structure of the food matrix can also impact individual physiological oral behaviour (e.g. salivation, throatcoating), and the strength, time and speed of chewing. This could lead to diverse cross-modal interactions, which are linked to both mechanical and biochemical degradations. In fact, panellist-specific mechanical chewing behaviours could impact the kinetics of aroma release and perception (Baek, et al., 1999; Déléris et al., 2011; Mestres, Kieffer, \& Buettner, 2006; Mestres et al., 2005). As shown by Gierczynski et al. (2008), this behaviour (i.e. chewing force, frequency and duration, as well as the opening and closing of the velum-tongue barrier) also depended on the structure of the matrix. These authors formulated the hypothesis that a firmer gel, which was perceived as granular and whose breakdown was heterogeneous, required more attention to the texture by the sub- 
ject than a softer gel did, which was perceived as smooth, spread, and thus more easily destroyed. As a consequence, for the firmer gel, less attention would be paid to other perceptions, such as taste and aroma, which would thus be perceived as less intense. An illustration of this phenomenon lies in the study of Hansson et al. (2003) in which aroma concentrations in the nose were found to be about twice as high when pectin-containing systems were chewed compared to when they were just being held in the mouth. This could be explained by the variable entrapment of the volatiles within the food matrix according to its destructuration in the mouth (Boland et al., 2006; Déléris et al., 2011; Gierczynski et al., 2008; Hansson et al., 2003; Kühn, Delahunty, Considine, \& Singh, 2009; Mestres et al., 2005; Mestres et al., 2006). Biochemical interactions between structuring agents and saliva components could also impact aroma perception. For instance, Ferry et al. (2006) revealed that starch pastes mixed efficiently with saliva. This was responsible for different mouthfeel and increased flavour perception in comparison with random coil polysaccharides. Another important factor in saliva is the presence of the enzyme alphaamylase, which can degrade starch and reduce the viscosity of matrices in a few seconds (Ferry, Hort, Mitchell, Lagarrigue, \& Valles-Pamies, 2004). If the viscosity signal reaching the brain modulates the processing of taste and aroma signals, such a reduction could be expected to contribute to enhancing flavour perception. Moreover, salivation is directly influenced by the specific food composition and results in a back-coupling effect on texture and aroma perception (Guinard, Zoumas-Morse, \& Walchak, 1998; Guinard, Zoumas-Morse, Walchak, \& Simpson, 1997; Mestres et al., 2006). For example, Guinard et al. (1998) revealed that the parotid saliva flow may correlate with the perception of some texture and mouthfeel attributes (presumably through oral work and bolus formation). As a consequence, one can speculate whether the perception of aroma would be modified as well.

As shown by Roudnitzky et al. (2011), psychological mechanisms must also be taken into account when dealing with texture-aroma interactions (Boland et al., 2006; Gierczynski et al., 2008; Hollowood et al., 2002; Lethuaut et al., 2004, 2005; Weel et al., 2002). An association between aroma and texture perceptions has also been observed in several works (e.g. a 'cream' aroma increased the creaminess of milk-like foods; Bult et al., 2007 or Saint-Eve et al., 2009).

Lastly, psychological and physiological mechanisms could overlap. In this connection, Gierczynski et al. (2008) showed that, in some cases, a firm matrix may require greater attention to chew it. As a consequence, less attention would be paid to other perceptions, such as taste and aroma, which would be perceived as less intense.

Given the diversity of cross-modal interactions between taste, texture and aroma, their study remains a tricky task, especially in complex or real food matrices. To date, 6the sensory and instrumental methods developed have mostly enabled interactions in model or reconstituted matrices to be analysed. In general, these contained defined amounts of taste or structuring compounds and ten or so standard volatiles. In such matrices, the methods used have determined both the occurrence of interactions and the physico-chemical, physiological or psychological phenomena from which they originated.

\section{Current sensory methods to analyse cross-modal interactions}

Until now, the two main methodologies applied to investigate interactions have been descriptive sensory analysis and dynamic sensory analysis. The first aims to quantify the intensity of several stimuli to produce a sensory profile. The second is designed to evaluate the intensity of a stimulus during food consumption. These methodologies are applied either alone or combined with instrumental tools. In both cases, they have been used to study the modification of perception of a stimulus in the presence of taste, structuring or aroma compounds added in various amounts in a stringently controlled fashion.

\subsection{Descriptive sensory analysis of aroma-related interactions}

In the last ten years, descriptive sensory analysis has been the most employed method to highlight aroma-related interactions. For instance, texture-aroma interactions were revealed by Hollowood et al. (2002) thanks to descriptive analysis. These authors showed a steady decrease in strawberry aroma intensity at high concentrations of a thickener in solutions.

During this analysis, judges were then asked to score selected attributes (taste, texture or aroma descriptors) while they were eating matrices of different compositions. In most cases, this was performed with a trained panel that was able to evaluate the intensity of selected descriptors (Table 1 ). In a few works, rating tasks were undertaken by naïve or experienced judges without specific training (Table 1 ). To verify panel performance, the overall session or one sample was replicated. A reference was also included within each session as a blind control. Samples were presented either monadically (Gierczynski et al., 2008; Hewson et al., 2008; Mestres et al., 2005; Saint-Eve et al., 2004; Saint-Eve et al., 2009) or in groups to reduce the sensory fatigue of judges (Boland et al., 2006; Hollowood et al., 2002).

Free choice profiling has also been performed to evaluate sensory interactions (Table 1 ). During this task, judges were asked both to identify attributes in the sample and to rate the intensity of those attributes. This method thus allowed judges to use their own attributes to describe products having a variable texture, taste or aroma, on its own descriptors. It can be noticed that the results obtained with this test were similar to those of a descriptive analysis (Saint-Eve et al., 2004).

While the effectiveness of sensory profiling for highlighting sensory interactions has been demonstrated, one of its main limitations is its inability to explain the origin of the interactions (e.g. Saint-Eve et al., 2004). As a consequence, sensory profiling has usually been associated with instrumental measurements (see paragraph 5). Moreover, it cannot quantify a given sensation during eating; instead it provides a snapshot of the potential interactions at a given time. It does not take into account the temporal physicochemical changes that a food product undergoes during consumption, and yet these changes are particularly important when studying aroma perception. In fact, as proposed by Overbosch (1986), the perception of aroma intensity is a dynamic and adaptive process. This adaptation depends on food breakdown and leads to a decreased or absent response when olfactory receptors are subjected to a constant flow of aroma. The dynamics of aroma perception are thus variable in the course of eating. They are a function of individual chewing and swallowing behaviour, and physiological properties (e.g. mucosa, saliva) (Baek et al., 1999). They also vary according to the food matrix composition since this triggers the force and time that individuals spend on chewing it (Gierczynski et al., 2008). Added to the fact that interactions may occur between volatiles at the receptor site, it could be speculated whether such "static" descriptive methods can identify the dynamics of sensory interactions in the course of eating.

\subsection{Dynamic sensory analysis of aroma-related interactions}

In order to consider the dynamics of food perception, the timeintensity (TI) method (Lee \& Pangborn, 1986) was applied to sensory interaction studies. This method monitors the intensity of a 
Data for one evaluation by one panellist

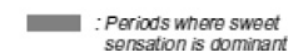

sensation is dominant

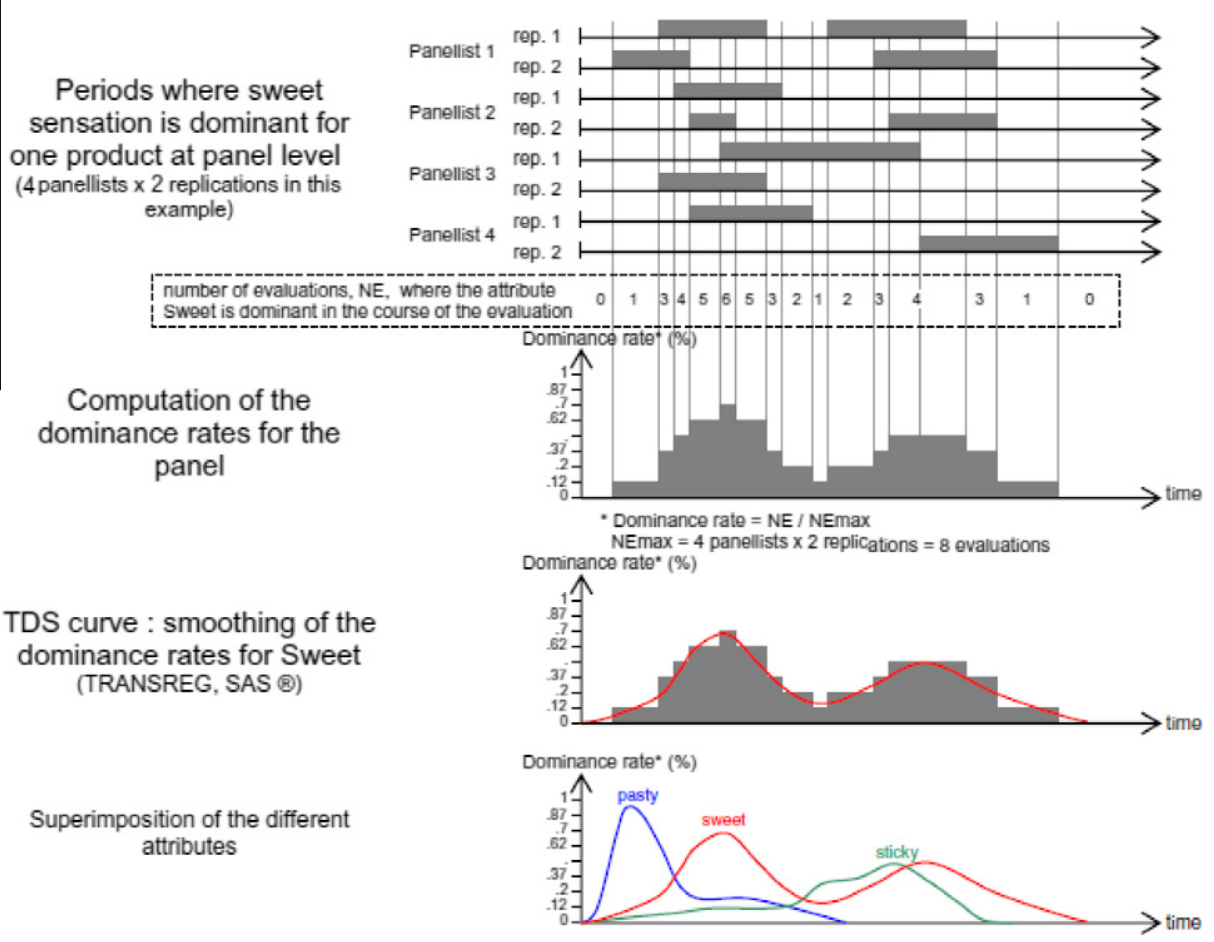

Fig. 1. Temporal dominance of sensations (Pineau et al., 2009) single descriptor over time. It thus provides more real, valid and dynamic information compared to descriptive methods (Dijksterhuis \& Piggott, 2001).

Over the past decade, aroma-involved interactions have been mainly studied by this method. The objective of TI was to determine whether the duration and intensity of a single stimulus (taste, texture or aroma) could change in the course of eating in the presence of another variable stimulus (Table 1 ). It was notably used to show the impact of taste or structuring compounds on aroma perception during eating. For example, Lethuaut et al. (2004) highlighted sweetness-aroma interactions thanks to TI recordings, showing a higher aroma intensity with a higher sucrose level in model dairy desserts.

In most cases, judges were trained to focus on the intensity of a specific stimulus and to follow its perceptual changes in matrices of variable composition. Usually one or a few descriptors and/or products were evaluated (Ventanas et al., 2010b). Only the descriptors which were found to discriminate between samples in a previous descriptive experiment were evaluated in $\mathrm{TI}$.

One drawback of the TI method is the small number of attributes and/or products which are evaluated in a single session (Table 1). Only one descriptor is assessed at a time. Studies in which more than one attribute was rated were all the more time-consuming. Moreover, in this case study, the halo-dumping effect could have been seen (e.g. Clark and Lawless (1994) pointed out an enhancement of sweetness scores of pseudo-beverages when panellists were given only one sweetness scale compared to when both flavour and sweetness scales were provided). Hence, the TI method may not yield the same results according to the instructions given to subjects (Noble, 1996). An additional weak point of $\mathrm{TI}$ is its inability to report any change in the quality of a stimulus. Yet, one can question whether a change in aroma quality during eating would lead to a different perception of taste or texture (and vice versa).

The temporal dominance of sensations (TDS) was developed to address this latter issue by Pineau et al. (2004). It enables a "dynamic sensory profile" of a food product to be obtained by asking panellists to assess the dominant attribute they perceive during consumption (Fig. 1).

Recently, TDS was used to study sensory interactions (Table 1). For instance, Saint-Eve et al. (2011) employed this method to highlight texture-aroma interactions. They revealed that the structure of model candies not only modified their overall aroma intensity but also the temporal evolution of aroma quality during and after consumption.

Like in the TI procedure, judges were trained to detect and evaluate attributes which were selected according to the results of a previous descriptive sensory analysis. Moreover, as shown by Saint-Eve et al. (2011), descriptive sensory analysis and TDS were in overall agreement and provided complementary results.

A limitation of TDS lies in the difficulty for panellists to employ many descriptors without being confused. The number of descriptors in TDS should not exceed eight to ten, whereas there is no such limit in regular descriptive analysis (Pineau et al., 2012). The selection of the attributes has to be performed carefully and in agreement with all the judges; every judge must be able to assess each descriptor. TDS therefore provides extra information in terms of the multidimensionality of interactions but, like descriptive analysis and $\mathrm{TI}$, it cannot distinguish their origins when it is employed alone.

\subsection{Looking for innovative sensory strategies}

To date, descriptive analysis and dynamic sensory methods have mostly been employed to study interactions in liquid or 
semi-solid matrices with a controlled composition. To our knowledge, no one has used them to analyse interactions in real foodstuffs with a complex aroma, taste and structure. In such products, a huge diversity of interactions (not only between aroma, taste, and texture but also trigeminal sensations) would interfere with those which are being intentionally studied. Added to the fact that descriptive analysis, TI and TDS are relatively complex methods (judges have to evaluate several descriptors simultaneously and/or consider a sample in the time course of eating), one might expect judges to have difficulty in assessing distinct and variable sensations at the same time. To overcome this problem, Labbe et al. (2006) and Saenz-Navajas et al. (2012) studied sensory interactions in complex matrices using more simple tests (ranking and sorting tasks) (Table 1). During these tests, judges were asked to wear nose-clips and/or to use glass lids to mask the aroma. In the first work, the authors studied interactions in commercial beverages to which they added two commercial complex flavourings. In the second one, the researchers studied interactions in reconstituted wines. These were obtained by mixing the complex non-volatile and volatile fractions of commercial wines. In both studies, judges were made to focus only on taste and aroma sensations and were not disturbed by the (similar) texture of the beverages. A comparable methodology was followed by Poinot et al. (2011) to analyse interactions during the consumption of apples (Table 1). In this work, aroma, taste and texture perceptions were masked by employing different masking agents separately or combined (nose-clips to mask aroma perception, malic acid to mask taste perception and a flavourless gum base to mask texture perception). One or several stimuli were then omitted during the consumption. Such a method (i.e. use of nose-clips and other masking agents) has the advantage of identifying the possible origins of the interactions in complex matrices. The authors were able to reveal the psychological origin of several aroma-taste and/or aroma-texture interactions (Labbe et al., 2006; Poinot et al., 2011; Saenz-Navajas, 2012) when the panellists evaluated the samples differently with and without masking agents. This is a major advantage of the use of masking agents compared to the classic procedures of descriptive analysis, TI and TDS. As mentioned above, whereas these latter tests can highlight sensory interactions, when employed alone they cannot provide an explanation of their origins. That is why they are mostly associated with instrumental measurements.

\section{Current instrumental analysis of aroma volatiles involved in cross-modal interactions}

To determine the origins of aroma-related interactions, instrumental methods have been implemented. This section will only focus on the in vitro and in vivo methods that enable the volatiles involved in sensory interactions to be investigated. However, in general, these methods were combined with physico-chemical measurements of matrix taste (e.g. sucrose concentration by refractometry, salt by Chloride Quantab Strip, Infrared Spectrometry with Fourier Transformation, protein precipitation) and/or structure (e.g. fluorescence microscopy, compression tests, diffraction particle size analyser, viscosity measurement). Physiological methodologies were also used in combination with measurements of volatiles. Mouth movements, chewing, swallowing and spitting were visualised in time-resolved video fluoroscopy recordings (e.g. Mestres et al., 2006) and real-time magnetic resonance imaging (MRI) (e.g. Buettner, Beer, Hannig, Settles, \& Schieberle, 2002). More recently, the electrophysiological approach, named chemosensory event-related potentials (ERP), was employed to investigate the neuro-temporal aspects of perceptual interactions (e.g. Roudnitzky et al., 2011).

\subsection{Static analysis of volatile compounds in sensory interactions}

Static in vitro extraction of the volatiles released from model matrices has mainly been performed using headspace methods (Boland et al., 2006; Déléris et al., 2011; Lethuaut et al., 2005; Weel et al., 2002; Zafeiropoulou et al., 2012), Solid Phase MicroExtraction (Keršienè et al., 2008; Kühn et al., 2009; Saint-Eve et al., 2009; Ventanas et al., 2010b) and liquid-liquid microextraction or solid phase extraction (Sáenz-Navajas, Campo, Fernández-Zurbano, Valentin, \& Ferreira, 2010) (Table 2). Identification and quantification of volatiles has been carried out with GC/FID and/or GC/ MS instruments. Overall, these methods have been used to determine the partition coefficient of volatile compounds between the air and food matrix (Boland et al., 2006; Zafeiropoulou et al., 2012). Physical and chemical interactions between volatiles and taste or structuring components have thus been revealed as well as whether the volatile compounds were more retained in a food matrix because of a modification of its structure. Interactions with a physico-chemical origin have therefore been highlighted by such methods.

\subsection{Dynamic analysis of volatiles in sensory interactions}

To monitor real-time changes in the concentration in the air of target volatiles, two distinct techniques were developed in the 90s: APCI-MS, "Atmospheric Pressure Chemical Ionisation - Mass Spectrometry" (Taylor, Linforth, Harvey, \& Blake, 2000) and PTR-MS, "Proton Transfer Reaction - Mass Spectrometry" (Lindinger, Hansel, \& Jordan, 1998).

Both methods have constituted a real progress in the dynamic study of volatiles involved in aroma-related interactions (Table 2). They have shown good reproducibility, linearity, and sensitivity (Table 3). Combined with in vitro extraction techniques, APCI-MS and PTR-MS can determine whether a taste (Heenan et al., 2012; Hewson et al., 2008; Siefarth et al., 2011) or a structuring compound (Baek et al., 1999; Déléris et al., 2011; González-Tomás et al., 2007; Hollowood et al., 2002) has an impact on the release of the volatile compounds incorporated into the matrix (Table 2). The physico-chemical temporal events involving volatiles and structuring or taste compounds were thus pointed out.

To analyse volatiles that reach the olfactory receptors, APCI-MS and PTR-MS techniques have also been linked to individual nostrils (Fig. 2), providing in-nose measurements, also called MS-nose (Linforth, Ingham, \& Taylor, 1996). MS-nose has been carried out in several works to investigate aroma-related interactions (Table 2). Judges had to be familiarised with the technique in order not to be too disturbed by the instrumental settings (Harvey \& Barra, 2003). A specific tasting protocol was also provided to subjects in order to avoid inter-individual differences while they were eating the matrices (Table 2). Overall, MS-nose showed the effect of taste or structuring compounds on (1) the nature and concentration of volatiles that reached the olfactory epithelium and (2) the kinetics of transfer of these volatiles into the nasal cavity. It also distinguished the physico-chemical, physiological or psychological origins of the interactions revealed by sensory tests (see paragraph 5).

Nevertheless, both methods have a major limitation. They can only be used for the analysis of interactions in model matrices. In fact, when mixtures of unknown compounds are to be investigated, the problem of identification is crucial. In practice, all the compounds that contribute to the aroma of a real foodstuff can rarely be monitored simultaneously with such technologies. Those that have very low thresholds and lie outside the detection limits cannot be followed (Taylor et al., 2000). In addition, minor fragment ions with the same $\mathrm{m} / \mathrm{z}$ value, and positional- and stereoisomers with the same molecular formula, remain barely determined (Lindinger et al., 1998; Taylor et al., 2000). In studies of aroma-related 
Table 2

Instrumental methodologies used to analyse volatiles in aroma-related interactions.

\begin{tabular}{|c|c|c|c|c|c|c|c|c|c|c|}
\hline Methodology & $\begin{array}{l}\text { Instrumental } \\
\text { methods }\end{array}$ & $\begin{array}{l}\text { Products/ } \\
\text { stimuli } \\
\text { evaluated }\end{array}$ & $\begin{array}{l}\text { Number of } \\
\text { different } \\
\text { products/ } \\
\text { stimuli } \\
\text { evaluated }\end{array}$ & $\begin{array}{l}\text { Number of } \\
\text { replications }\end{array}$ & $\begin{array}{l}\text { Number } \\
\text { of } \\
\text { volatiles } \\
\text { followed }\end{array}$ & $\begin{array}{l}\text { Number } \\
\text { of } \\
\text { assessors }\end{array}$ & $\begin{array}{l}\text { Tasting } \\
\text { protocol }\end{array}$ & Raw data & $\begin{array}{l}\text { Combined with } \\
\text { sensory } \\
\text { evaluation }\end{array}$ & References \\
\hline \multirow[t]{9}{*}{$\begin{array}{c}\text { Static in vitro } \\
\text { analysis }\end{array}$} & \multirow[t]{9}{*}{$\begin{array}{l}\text { Headspace or } \\
\text { SPME/GC- } \\
\text { FID/MS }\end{array}$} & $\begin{array}{l}\text { Gelatine } \\
\text { and } \\
\text { pectin } \\
\text { gels }\end{array}$ & 6 & $3 /$ product & 10 & & & $\begin{array}{l}\text { - Peak area } \\
\text { - Headspace/ } \\
\text { product parti- } \\
\text { tion coefficients }\end{array}$ & $\begin{array}{l}\text { Descriptive } \\
\text { sensory analysis }\end{array}$ & $\begin{array}{l}\text { Boland et al. } \\
\text { (2006) }\end{array}$ \\
\hline & & $\begin{array}{l}\text { Model } \\
\text { candies }\end{array}$ & 4 & $3 /$ product & 3 & & & & $\begin{array}{l}\text { Descriptive } \\
\text { sensory analysis } \\
\text { and Temporal } \\
\text { Dominance of } \\
\text { Sensations }\end{array}$ & $\begin{array}{l}\text { Déléris et al. } \\
\text { (2011) and } \\
\text { Saint-Eve } \\
\text { et al. (2011) }\end{array}$ \\
\hline & & $\begin{array}{l}\text { Model } \\
\text { custard } \\
\text { desserts }\end{array}$ & 4 & $3 /$ product & 5 & & & & No & $\begin{array}{l}\text { Keršienė et al. } \\
\text { (2008) }\end{array}$ \\
\hline & & Solutions & 4 & ${ }^{*}$ & 1 & & & & No & $\begin{array}{l}\text { Kühn et al. } \\
\text { (2009) }\end{array}$ \\
\hline & & $\begin{array}{l}\text { Model } \\
\text { dairy } \\
\text { desserts }\end{array}$ & 27 & $3 /$ product & 4 & & & & $\begin{array}{l}\text { Descriptive } \\
\text { sensory analysis }\end{array}$ & $\begin{array}{l}\text { Lethuaut et al. } \\
\text { (2005) }\end{array}$ \\
\hline & & $\begin{array}{l}\text { Model } \\
\text { cheeses }\end{array}$ & 5 & $3 /$ product & 3 & & & & $\begin{array}{l}\text { Descriptive } \\
\text { sensory analysis }\end{array}$ & $\begin{array}{l}\text { Saint-Eve } \\
\text { et al. (2009) }\end{array}$ \\
\hline & & $\begin{array}{l}\text { Cooked } \\
\text { bologna } \\
\text { type } \\
\text { sausages }\end{array}$ & 9 & $3 /$ product & 2 & & & & $\begin{array}{l}\text { Descriptive } \\
\text { sensory analysis } \\
\text { and time- } \\
\text { intensity }\end{array}$ & $\begin{array}{l}\text { Ventanas et al. } \\
\text { (2010b) }\end{array}$ \\
\hline & & $\begin{array}{l}\text { Whey } \\
\text { protein } \\
\text { gels }\end{array}$ & 30 & ${ }^{*}$ & 2 & & & & Time-intensity & $\begin{array}{l}\text { Weel et al. } \\
(2002)\end{array}$ \\
\hline & & $\begin{array}{l}\text { Gelatine } \\
\text { gels }\end{array}$ & 4 & * & 8 & & & & No & $\begin{array}{l}\text { Zafeiropoulou } \\
\text { et al. (2012) }\end{array}$ \\
\hline \multirow[t]{7}{*}{$\begin{array}{l}\text { Dynamic } \\
\text { in vitro } \\
\text { analysis }\end{array}$} & \multirow[t]{4}{*}{$\begin{array}{l}\text { Headspace/ } \\
\text { APCI-MS }\end{array}$} & $\begin{array}{l}\text { Gelatine } \\
\text { gels }\end{array}$ & 3 & $2 /$ product & 1 & & & \multirow{4}{*}{$\begin{array}{l}\text { - Maximum } \\
\text { aroma intensity } \\
\text { (Imax) } \\
\text { - Times at which } \\
\text { Imax occurred } \\
\text { (tmax) } \\
\text { - Cumulative } \\
\text { area under the } \\
\text { curve (AUC) }\end{array}$} & $\begin{array}{l}\text { Descriptive } \\
\text { sensory analysis } \\
\text { and time- } \\
\text { intensity }\end{array}$ & $\begin{array}{l}\text { Baek et al. } \\
\text { (1999) }\end{array}$ \\
\hline & & $\begin{array}{l}\text { Model } \\
\text { custard } \\
\text { desserts }\end{array}$ & 8 & $2 /$ product & 4 & & & & $\begin{array}{l}\text { Paired } \\
\text { comparison } \\
\text { tests }\end{array}$ & $\begin{array}{l}\text { González- } \\
\text { Tomás et al. } \\
\text { (2007) }\end{array}$ \\
\hline & & Solutions & 135 & $5 /$ product & 2 & & & & $\begin{array}{l}\text { Descriptive } \\
\text { sensory analysis }\end{array}$ & $\begin{array}{l}\text { Hewson et al. } \\
(2008)\end{array}$ \\
\hline & & Solutions & 45 & * & 1 & & & & $\begin{array}{l}\text { Descriptive } \\
\text { sensory analysis }\end{array}$ & $\begin{array}{l}\text { Hollowood } \\
\text { et al. (2002) }\end{array}$ \\
\hline & $\begin{array}{l}\text { Volatile } \\
\text { aroma } \\
\text { stripping } \\
\text { kinetic/PTR- } \\
\text { MS }\end{array}$ & $\begin{array}{l}\text { Model } \\
\text { candies }\end{array}$ & 4 & $3 /$ product & 3 & & & \multirow{3}{*}{$\begin{array}{l}\text { - Maximum } \\
\text { aroma intensity } \\
\text { (Imax) } \\
\text { - Times at which } \\
\text { Imax occurred } \\
\text { (tmax) } \\
\text { - Cumulative } \\
\text { area under the } \\
\text { curve (AUC) }\end{array}$} & $\begin{array}{l}\text { Descriptive } \\
\text { sensory analysis } \\
\text { and Temporal } \\
\text { Dominance of } \\
\text { Sensations }\end{array}$ & $\begin{array}{l}\text { Déléris et al. } \\
\text { (2011) }\end{array}$ \\
\hline & $\begin{array}{l}\text { Headspace/ } \\
\text { PTR-MS }\end{array}$ & Solutions & 15 & $\begin{array}{l}2 \text { or } 3 / \\
\text { product }\end{array}$ & 4 & & & & No & $\begin{array}{l}\text { Siefarth et al. } \\
\text { (2011) }\end{array}$ \\
\hline & $\begin{array}{l}\text { Headspace/ } \\
\text { PTR-TOF-MS }\end{array}$ & $\begin{array}{l}\text { Model } \\
\text { cereal } \\
\text { bars }\end{array}$ & 8 & $3 /$ product & 18 & & & & No & $\begin{array}{l}\text { Heenan et al. } \\
(2012)\end{array}$ \\
\hline \multirow[t]{7}{*}{$\begin{array}{l}\text { Dynamic } \\
\text { in vivo } \\
\text { analysis }\end{array}$} & \multirow[t]{7}{*}{$\begin{array}{l}\text { APCI-MS- } \\
\text { Nose }\end{array}$} & $\begin{array}{l}\text { Gelatine } \\
\text { gels }\end{array}$ & 5 & * & 1 & 11 & No & \multirow{7}{*}{$\begin{array}{l}\text { - Maximum } \\
\text { aroma intensity } \\
\text { (Imax) } \\
\text { - Times at which } \\
\text { Imax occurred } \\
\text { (tmax) } \\
\text { - Intensity of the } \\
\text { APCI-MS signal } \\
\text { when the prin- } \\
\text { cipal swallow } \\
\text { occurs } \\
\text { (Iswallow) } \\
\text { - Cumulative } \\
\text { area under the } \\
\text { curve (AUC) }\end{array}$} & $\begin{array}{l}\text { Descriptive } \\
\text { sensory analysis } \\
\text { and time- } \\
\text { intensity }\end{array}$ & $\begin{array}{l}\text { Baek et al. } \\
\text { (1999) }\end{array}$ \\
\hline & & Milk gels & 3 & $\begin{array}{l}8 / \text { product/ } \\
\text { judge }\end{array}$ & 6 & 14 & Yes & & $\begin{array}{l}\text { Descriptive } \\
\text { sensory analysis }\end{array}$ & $\begin{array}{l}\text { Gierczynski } \\
\text { et al. (2008) }\end{array}$ \\
\hline & & $\begin{array}{l}\text { Model } \\
\text { dairy } \\
\text { custards }\end{array}$ & 8 & No & 4 & 10 & No & & $\begin{array}{l}\text { Paired } \\
\text { comparison } \\
\text { tests }\end{array}$ & $\begin{array}{l}\text { González- } \\
\text { Tomás et al. } \\
(2007)\end{array}$ \\
\hline & & Solutions & 8 and 45 & * & 2 & 13 & Yes & & $\begin{array}{l}\text { Descriptive } \\
\text { sensory analysis }\end{array}$ & $\begin{array}{l}\text { Hollowood } \\
\text { et al. ( } 2002)\end{array}$ \\
\hline & & Solutions & 3 & $\begin{array}{l}\text { 2/product/ } \\
\text { judge }\end{array}$ & 1 & 15 & No & & Time-intensity & $\begin{array}{l}\text { Hort and } \\
\text { Hollowood } \\
(2004)\end{array}$ \\
\hline & & $\begin{array}{l}\text { Model } \\
\text { dairy } \\
\text { desserts }\end{array}$ & 6 & $\begin{array}{l}\text { 6/product/ } \\
\text { judge }\end{array}$ & 4 & 7 & Yes & & Time-intensity & $\begin{array}{l}\text { Lethuaut et al., } \\
2004\end{array}$ \\
\hline & & $\begin{array}{l}\text { Model } \\
\text { custard } \\
\text { desserts }\end{array}$ & 4 & $\begin{array}{l}\text { 6/product/ } \\
\text { judge }\end{array}$ & 2 & 6 and 15 & Yes & & Rating task & $\begin{array}{l}\text { Tournier et al. } \\
\text { (2009) }\end{array}$ \\
\hline
\end{tabular}


Table 2 (continued)

\begin{tabular}{|c|c|c|c|c|c|c|c|c|c|c|}
\hline Methodology & $\begin{array}{l}\text { Instrumental } \\
\text { methods }\end{array}$ & $\begin{array}{l}\text { Products/ } \\
\text { stimuli } \\
\text { evaluated }\end{array}$ & $\begin{array}{l}\text { Number of } \\
\text { different } \\
\text { products/ } \\
\text { stimuli } \\
\text { evaluated }\end{array}$ & $\begin{array}{l}\text { Number of } \\
\text { replications }\end{array}$ & $\begin{array}{l}\text { Number } \\
\text { of } \\
\text { volatiles } \\
\text { followed }\end{array}$ & $\begin{array}{l}\text { Number } \\
\text { of } \\
\text { assessors }\end{array}$ & $\begin{array}{l}\text { Tasting } \\
\text { protocol }\end{array}$ & Raw data & $\begin{array}{l}\text { Combined with } \\
\text { sensory } \\
\text { evaluation }\end{array}$ & References \\
\hline & \multirow{8}{*}{ PTR-MS-Nose } & $\begin{array}{l}\text { Whey } \\
\text { protein } \\
\text { gels }\end{array}$ & 10 & $\begin{array}{l}\text { 3/product/ } \\
\text { judge }\end{array}$ & 2 & 10 & Yes & & Time-intensity & $\begin{array}{l}\text { Weel et al. } \\
(2002)\end{array}$ \\
\hline & & $\begin{array}{l}\text { Model } \\
\text { emulsions }\end{array}$ & 6 & No & 2 & 7 & Yes & \multirow{2}{*}{$\begin{array}{l}\text { - Maximum } \\
\text { aroma intensity } \\
\text { (Imax) } \\
\text { - Times at which } \\
\text { Imax occurred } \\
\text { (tmax) }\end{array}$} & $\begin{array}{l}\text { Descriptive } \\
\text { sensory analysis }\end{array}$ & $\begin{array}{l}\text { Arancibia } \\
\text { et al. (2011) }\end{array}$ \\
\hline & & $\begin{array}{l}\text { Gelatine } \\
\text { and } \\
\text { pectin } \\
\text { gels }\end{array}$ & 6 & $\begin{array}{l}\text { 4/product/ } \\
\text { judge }\end{array}$ & 4 & 12 & No & & $\begin{array}{l}\text { Descriptive } \\
\text { sensory analysis }\end{array}$ & $\begin{array}{l}\text { Boland et al. } \\
(2006)\end{array}$ \\
\hline & & $\begin{array}{l}\text { Model } \\
\text { candies }\end{array}$ & 4 & $\begin{array}{l}\text { 4/product/ } \\
\text { judge }\end{array}$ & 3 & 12 & Yes & $\begin{array}{l}\text { - Cumulative } \\
\text { area under the } \\
\text { curve (AUC) }\end{array}$ & $\begin{array}{l}\text { Descriptive } \\
\text { sensory analysis } \\
\text { and Temporal } \\
\text { Dominance of } \\
\text { Sensations }\end{array}$ & $\begin{array}{l}\text { Déléris et al. } \\
\text { (2011) and } \\
\text { Saint-Eve } \\
\text { et al. (2011) }\end{array}$ \\
\hline & & Solutions & 10 & $\begin{array}{l}5 / \text { product/ } \\
\text { judge }\end{array}$ & 1 & 3 & Yes & & No & $\begin{array}{l}\text { Kühn et al. } \\
\text { (2009) }\end{array}$ \\
\hline & & $\begin{array}{l}\text { Pectin } \\
\text { gels }\end{array}$ & 4 & $\begin{array}{l}\text { 3/product/ } \\
\text { judge }\end{array}$ & 4 & 1 & Yes & & No & $\begin{array}{l}\text { Hansson et al. } \\
\text { (2003) }\end{array}$ \\
\hline & & Yogurts & 13 & $\begin{array}{l}2-3 / \\
\text { product/ } \\
\text { judge }\end{array}$ & 3 & 2 & No & & No & $\begin{array}{l}\text { Mei et al. } \\
(2004)\end{array}$ \\
\hline & & $\begin{array}{l}\text { Protein } \\
\text { gels }\end{array}$ & 2 & $\begin{array}{l}\text { 3/product/ } \\
\text { judge }\end{array}$ & 1 & 7 & Yes & & $\begin{array}{l}\text { Descriptive } \\
\text { sensory analysis } \\
\text { and time- } \\
\text { intensity }\end{array}$ & $\begin{array}{l}\text { Mestres et al. } \\
(2005) \\
\text { Mestres et al. } \\
(2006)\end{array}$ \\
\hline & $\begin{array}{l}\text { PTR-TOF-MS- } \\
\text { Nose }\end{array}$ & $\begin{array}{l}\text { Model } \\
\text { cereal } \\
\text { bars }\end{array}$ & 8 & $\begin{array}{l}\text { 2/product/ } \\
\text { judge }\end{array}$ & 18 & 5 & No & $\begin{array}{l}\text { - Total area of the } \\
\text { flavour profile } \\
\text { curves (Amax) } \\
\text { - Maximum } \\
\text { intensity (Imax) } \\
\text { - Time required } \\
\text { to attain the } \\
\text { Imax (tmax) } \\
\text { - Time between } \\
\text { "in mouth" and } \\
\text { first swallowing } \\
\text { (tswa) }\end{array}$ & No & $\begin{array}{l}\text { Heenan et al. } \\
(2012)\end{array}$ \\
\hline
\end{tabular}

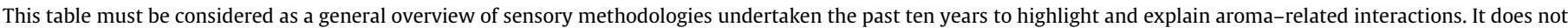
claim to list all sensory studies performed on aroma-related interactions.

Table 3

Advantages and drawbacks of APCI-MS and PTR-MS techniques.

\begin{tabular}{|c|c|c|}
\hline & APCI-MS & PTR-MS \\
\hline Advantages & $\begin{array}{l}\text { - Sensitivity: detection of volatiles at concentration about } 1 \mathrm{ppb} \\
\text { - } 80 \% \text { of volatile compounds can be detected when they are at a concentration range around } \\
\text { their detection threshold } \\
\text { - Routinely used for in vivo analyses since } 1996 \\
\text { - Frequently used in sensory interaction studies } \\
\text { - Linear response of signal/noise ratio for compound concentrations between } 1 \mathrm{ppb} \text { and } 2 \mathrm{ppm} \\
\text { - Molecules monitored with a specific } \mathrm{m} / \mathrm{z} \text { ratio; reduction of fragment overlapping } \\
\text { - Can be combined with instrumental extraction techniques (headspace) or adapted for in vivo e } \\
\text { - For in vivo analyses, do not require a specific train of judges }\end{array}$ & $\begin{array}{l}\text { - Sensitivity: detection of volatiles at concentra- } \\
\text { tion about } 1 \mathrm{ppt} \\
\text { - Recently used in sensory interaction studies } \\
\text { - Controlled ionisation and identification } \\
\text { - Accurate quantification } \\
\text { exhaled air measurements }\end{array}$ \\
\hline Drawbacks & $\begin{array}{l}\text { - Variable selectivity in compounds ionisation } \\
\text { - Provide non-quantitative results } \\
\text { - Fragmentation of some compounds (alcohols et aldehydes) } \\
\text { - Overall, a few of volatiles with specific } \mathrm{m} / \mathrm{z} \text { ratio can be monitored simultaneously }(<10) \\
\text { - Can only be used for the analysis of simple mix of aroma compounds } \\
\text { - Difficulty to differentiate between ions characterised by the same } \mathrm{m} / \mathrm{z} \text { ratio }\end{array}$ & $\begin{array}{l}\text { - Cost } \\
\text { - Complex }\end{array}$ \\
\hline
\end{tabular}

Data from Biasioli et al. (2006), Blake, Monks, and Ellis (2009), Harvey and Barra (2003), Linforth et al. (1996) and Taylor et al. (2000).

interactions, researchers thus had to reach a compromise between the number of volatiles monitored and their signal-to-noise ratio. Only 1 to 6 volatiles were therefore targeted during such experiments (Table 2) while volatiles displaying a signal below the detection limit were not considered (Boland et al., 2006; Déléris et al., 2011; González-Tomás et al., 2007; Hansson et al., 2003).
Recently, to improve sensitivity and accuracy when more than 10 compounds had to be analysed, APCI and PTR interfaces were connected to a time of flight mass spectrometer (TOF-MS). PTR-TOF-MS was applied by Heenan et al. (2012) to study taste-aroma interactions in complex matrices (model cereal bars). 


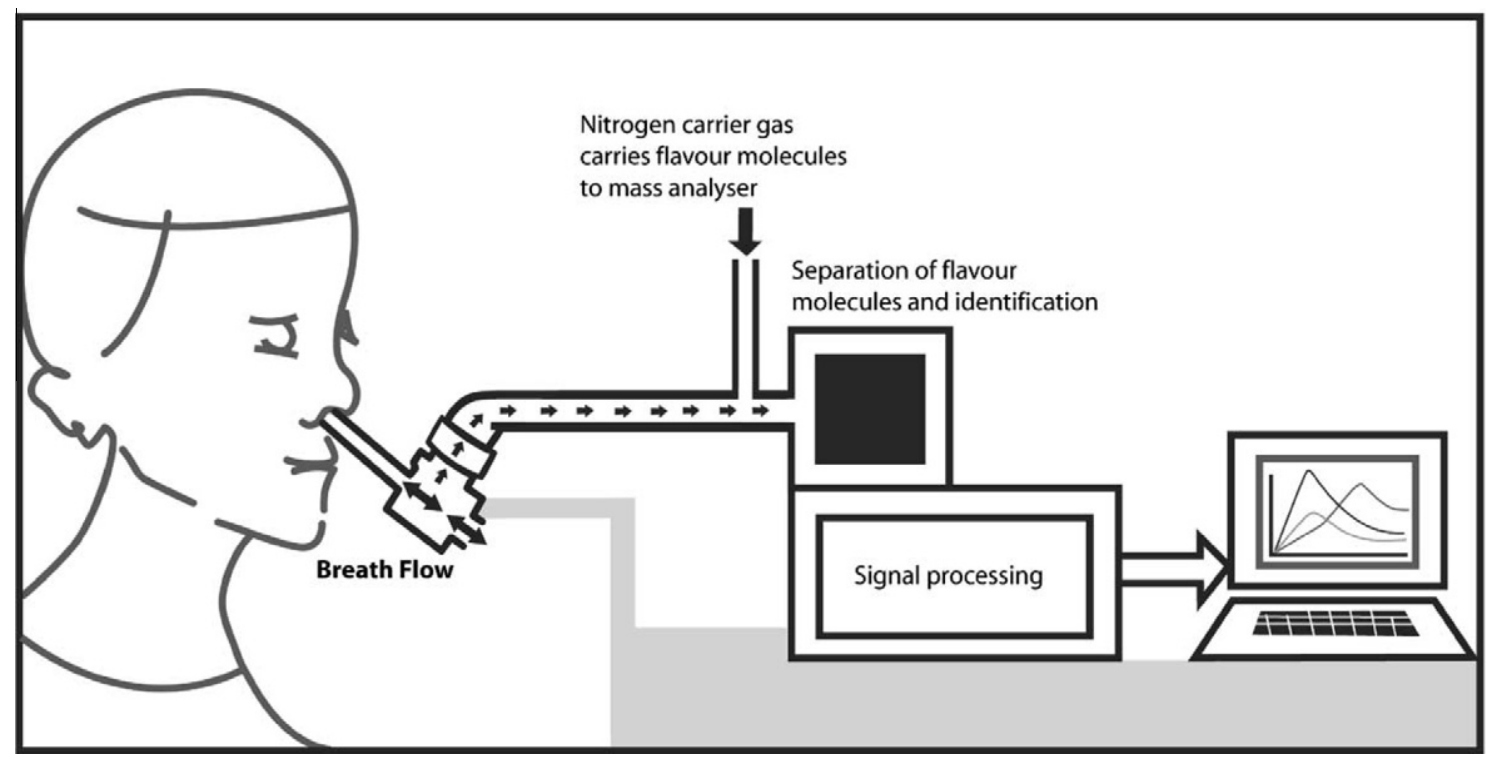

Fig. 2. Schematic diagram of nose-space analysis (Harvey \& Barra, 2003).

\section{For a better understanding of cross-modal interactions: link sensory and instrumental methods}

Combining sensory analysis and instrumental measurements has become the most recognised approach to study sensory interactions.

Nowadays, most aroma-related interactions are investigated through the association of descriptive sensory analysis with dynamic in vitro or in vivo instrumental analyses (Table 2). This approach has been really effective for studying interactions in model food matrices. It has clearly highlighted sensory interactions and distinguished their physico-chemical, physiological or psychological origins. For instance, by comparing the data of a descriptive sensory analysis with those of static headspace-APCI-MS measurements, Hewson et al. (2008) pointed out taste-aroma interactions in model solutions. These authors showed that the intensity of their citrus aroma was increased on addition of tastants (lactic acid, citric acid, glucose and fructose). On the other hand, the concentrations of the volatiles released from the solutions remained the same. Such findings allowed the authors to discuss the psychological origin of these taste-aroma interactions. Following the same approach, texture-aroma interactions have also been revealed in various model matrices. Those having a psychological origin have been shown when sensory and instrumental data were not in accordance (Arancibia et al., 2011; Boland et al., 2006; Gierczynski et al., 2008; Hollowood et al., 2002). Physico-chemical interactions have also been highlighted (Arancibia et al., 2011; González-Tomás et al., 2007). For example, thanks to a descriptive analysis, Arancibia et al. (2011) observed a significant decrease in citrus flavour scores when oil concentration was increased in oil/water emulsions. This result was linked to a decrease in the release of linalool as shown by in vivo measurement of volatiles. The authors discussed the hydrophobic interactions between linalool and oil. In addition, interactions due to individual physiological behaviours have been highlighted (Gierczynski et al., 2008) and their link to the physico-chemical characteristics of the matrix has been demonstrated (Boland et al., 2006; Gierczynski et al., 2008). The authors found that individual masticatory efforts were different according to the structure of the matrix. This led to variable kinetics and concentrations of the volatiles released from the matrix, which could have an effect on aroma perception. Moreover, this methodology highlighted the link between the panellists' specific aroma-release and their aroma perception (Gierczynski et al., 2008).
To study the dynamics of sensory interactions better, some authors have associated the TI method with MS-nose analyses (Table 2). The temporal effect of taste or a structuring agent on the release and perception of volatiles has thus been investigated. The kinetics of volatile release and aroma perception were roughly superimposable whatever the matrix studied (Baek et al., 1999; Lethuaut et al., 2004; Weel et al., 2002). Overall, the highest concentration of volatiles in the nasal cavity and the maximum aroma intensity were both shown to occur just after swallowing. Thanks to this approach, some taste components (Lethuaut et al., 2004) and structuring agents (Baek et al., 1999; Déléris et al., 2011; Lethuaut et al., 2004; Mestres et al., 2006; Weel et al., 2002) were shown to have an effect on both the level of volatiles released in the nose and the intensity of the aroma perceived. The dynamics of aroma quality have also been investigated by associating TDS with PTR-MS-nose (Déléris et al., 2011; Saint-Eve et al., 2011). In fact, the authors revealed that the structure of model candies not only modified their overall aroma intensity but also the change in aroma quality during and after consumption. The origins of such interactions were also highlighted. When TI and MS-nose data were correlated, interactions which had a physico-chemical and/ or physiological origin were reported (e.g. Déléris et al., 2011). This has also revealed a clear correlation between the matrix structure, physiological individual-specific behaviours and the kinetics of sensory perception (Déléris et al., 2011; Mestres et al., 2006). When TI and MS-nose data did not agree, psychological interactions were proposed (e.g. Lethuaut et al., 2004; Weel et al., 2002). An illustration of this lies in the work of Lethuaut et al. (2004) who highlighted a large sucrose effect on 'fruity' aroma TI recordings with a limited sucrose effect on aroma release. The impact of sweetness on aroma perception was thus considered mainly perceptual.

\section{Future approaches to studying aroma-related cross-modal interactions}

Over the past decade, the study of aroma-related interactions has been mainly achieved by using both instrumental methods (i.e. headspace or MS-nose) and sensory analyses (i.e. descriptive analysis or TI). Taste-aroma and texture-aroma interactions have thus been highlighted in various food matrices. Their physico- 


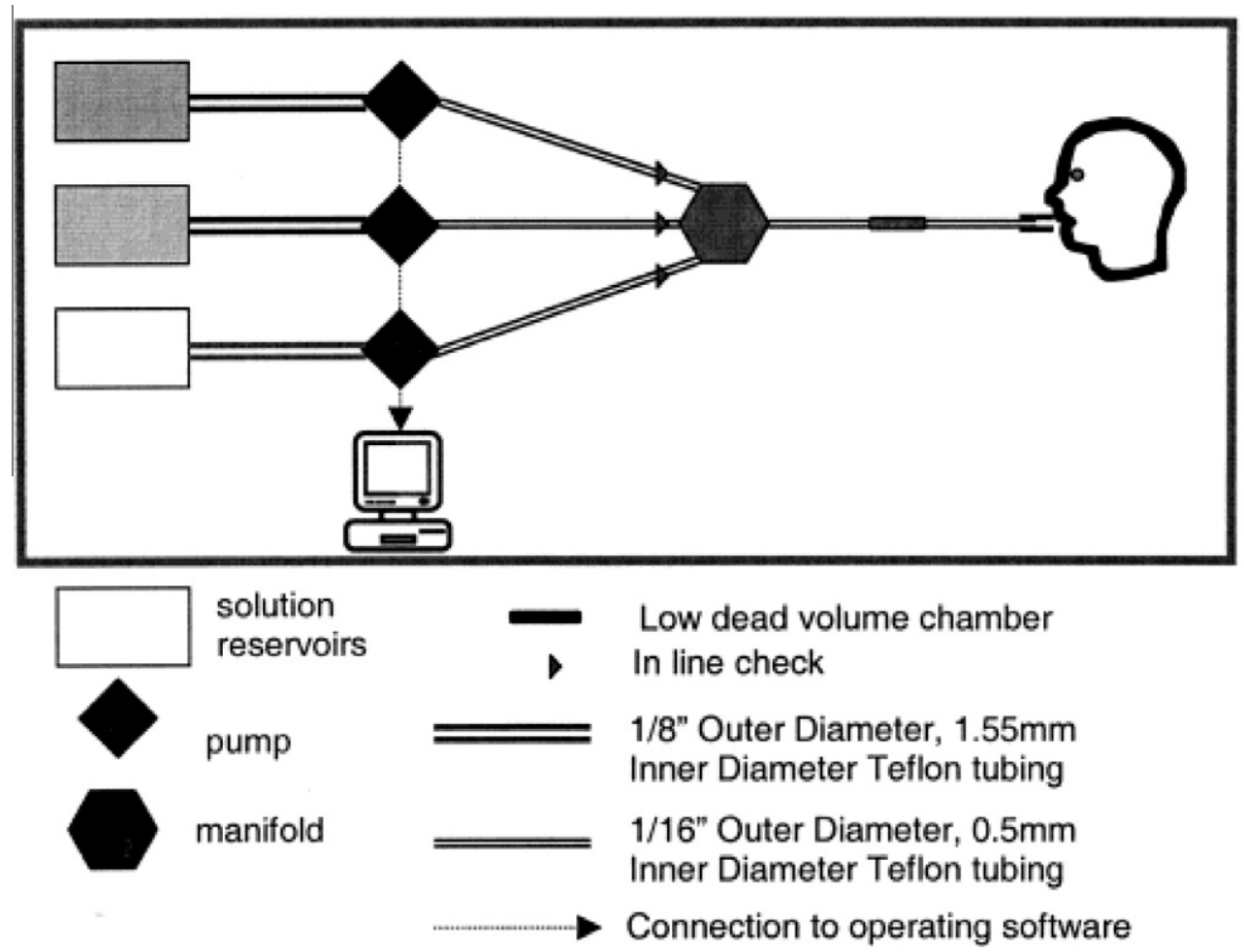

Fig. 3. Scheme of the dynataste multichannel flavor delivery system (Hort \& Hollowood, 2004).

chemical, physiological or psychological origins have also been determined. This approach has proved its efficacy especially for model food matrices. Yet, one can question its value when analysing sensory interactions in real foodstuffs. For example, one of the major limitations of MS-nose techniques is their inability to quantify more than ten volatile compounds in the nasal exhalations of individuals.

An objective of new methodologies would therefore be to follow simultaneously the volatiles of a complex mixture that reach the olfactory epithelium while the subject is scoring the taste, texture or aroma sensation he/she perceives. To this end, Burseg and de Jong (2009) developed a new apparatus called the Olfactoscan which can identify binary aroma interactions in real food matrices (i.e. volatile masking effects).

Moreover, present approaches are not wholly comparable to natural eating, which involves the oral delivery of several stimuli at the same time, stimuli that could vary during consumption. To investigate the cross- and intermodality of flavour perception/ stimuli, Hort and Hollowood (2004) built a new device, called the Dynastate. This is a multichannel flavour delivery system that enables the continuous delivery of a sample (Fig. 3) and mimics food consumption over more realistic time periods. The authors revealed that changing the concentrations of taste components during the consumption of solutions resulted in changes in the intensity of their aroma. In this case study, taste-aroma interactions were shown to occur at a perceptual level. Comparable systems were further used to investigate taste-aroma interactions in a model solution using odorants at subthreshold concentrations (Labbe et al., 2007). Binary taste interactions were also studied (Morris et al., 2010).

A similar procedure was set up by Bult et al. (2007). They presented a specially-developed computer-controlled system of airdilution olfactometry and pumps. It could send to the judges' mouths different milk solutions with or without a thickener, in addition or not to a 'cream' odour presented ortho- or retronasally. This system was next used by Burseg et al. (2010) to study the ef- fects of pulsatile delivery of aroma and taste on their combined contribution to taste intensity. More recently, it was combined with ERP recordings, to analyse more precisely the effect of two different texture stimuli on the perception of a 'butter' aroma (Roudnitzky et al., 2011). In this work, the authors highlighted that interactions between texture and odour occurred at both primarysensory and cognitive evaluative levels of stimulus processing. They also showed that the temporal dimension played a critical role in the investigation of odour-texture interactions.

This system, like the Dynataste, provides an original approach to investigate taste-aroma and texture-aroma interactions that involve a complex aroma. To go further, it would be interesting to develop a device to study aroma-related interactions during the eating of real food products (notably hard foodstuffs). However, because of the complexity of such matrices, their analysis would have to be simplified. This could be done, for instance, by disconnecting the different stimuli that judges have to perceive (aroma, taste and texture) such that their physico-chemical, physiological and psychological origins would be analysed separately. This procedure would have considerable potential in tandem with MS-nose methodologies, by helping to determine the mechanisms which trigger cross-modal interactions during the eating of real foodstuffs.

\section{Conclusion}

This paper reviews the current methods developed to analyse aroma-related interactions. Up to now, such interactions have mainly been studied by combining sensory analysis with the dynamic instrumental measurement of volatiles.

Among the sensory tests used, descriptive sensory analysis has demonstrated its efficacy. It aims to show the impact of a stimulus (aroma, taste or texture) on the perception of other stimuli by describing them through various attributes. It has the advantage of providing a multidimensional profile of the sensory interactions. Moreover, since judges are trained to focus on the sensation that is 
expected to be modified under the variable conditions, the interactions are generally identified unambiguously. However, the weakness of this method lies in its inability to take into account the dynamics of interactions. In this case, time-intensity (TI) and temporal dominance of sensations (TDS) methods would be preferable. Their objective is to determine whether the perception of a stimulus (aroma, taste or texture) varies during eating, while different amounts of another stimulus are incorporated into the matrix studied. TI has the advantage of evaluating the intensity of the stimulus while TDS evaluates its quality. These benefits can also be considered as their main drawbacks. For example, TI cannot easily be applied to score several descriptors/products in the same session, which can lead to halo-dumping effects. TDS, on the other hand, may lead to a confusion of the panellist due to their difficulty in considering several descriptors over a short period of time. Compared to descriptive sensory analysis, in which the training of the panel is standardised, the training in TI and TDS differs from one study to another. So, TI and TDS may lead to variable results according to the instructions given to the judges.

The recruitment of trained or experienced judges in descriptive, TI or TDS methods can also be discussed when studying sensory interactions. In fact, one of the objectives of sensory training is to make the panellists able to differentiate distinct stimuli when coexposure is carried out. Judges should therefore avoid associative learning whereas this is expected in sensory interactions (and more especially in psychological ones). In the same way, since judges are generally trained to follow a common eating protocol, the physico-chemical and physiological interactions linked to individual chewing behaviours may be standardised. Thus, it may be that convening naïve subjects would be a better approach to be more representative of consumer perception. Following this tactic, discriminative tests (e.g. sorting tasks) have recently been applied. To learn about interactions due to this kind of test, masking agents were used to block the perception of one or several stimuli (e.g. nose-clips, hard flavourless gum or malic acid). With these materials, it was possible to determine the origin of interactions (notably those having a psychological origin). This is not feasible with the classic procedure of descriptive, TI and TDS methods which, employed alone, cannot conclude about the origin of the interactions. When the mechanisms from which aroma-related interactions originate must be explained, descriptive, TI and TDS methods must thus be associated with instrumental measurements.

Overall, two main instrumental methods have been applied to explain aroma-related interactions. The first corresponds to the static analysis of volatiles using headspace or SPME techniques. They aim to determine the partition coefficient of volatile compounds between the air and the food matrix. The effect of taste or structuring components on volatile release can thus be highlighted. In association with sensory methods, they can distinguish interactions with a psychological origin from those arising from physico-chemical events. These methods have the advantage of being affordable and practicable. However, they do not lead either to the physiological issues or to the dynamics of interactions.

The second instrumental method corresponds to the dynamic analysis of volatiles involved in interactions. It can be performed with APCI-MS or PTR-MS devices. These are generally linked to individual nostrils, forming MS-nose techniques. They aim to show the impact of taste or structuring agents on the type and concentration of volatiles reaching the olfactory epithelium during eating. Combined with static instrumental methods and descriptive sensory analysis, they can distinguish interactions with a physicochemical, physiological or psychological origin. Their association with TI and TDS methods increases the understanding of interactions by giving additional information about the temporal effect of taste or structuring compounds on the release of volatiles and their perception. Despite the efficacy of MS-nose techniques in studying aroma-related interactions in model food matrices in which ten or so volatiles are added, they cannot be applied to study interactions in complex food matrices. In fact, they can only quantify a few volatile compounds in the nasal exhalations of individuals. As a result, analysing interactions which involve a complex aroma remains complicated with such devices. Innovative tools, like the Olfactoscan, the Dynastate and derivatives, have been developed to address this issue. Nevertheless, these cannot be applied to study interactions in real and hard foodstuffs.

In conclusion, even though numerous sensory and instrumental methods have been developed to analyse taste-aroma and texture-aroma interactions in model food matrices, there is still much to be done to highlight and explain these interactions in real food matrices. In fact, there is a real gap in our understanding of whether sensations act independently or in interaction throughout food intake. Continuous progress can therefore be expected to identify those factors which affect overall aroma perception during the consumption of real foodstuffs.

\section{Acknowledgements}

This review was carried out under the COSIVEG programme with financial support from the Région Pays de la Loire. We gratefully acknowledge Emira Mehinagic, Florence Texier, Laurent Lethuaut and Evelyne Vigneau for their involvement in studies related to cross-modal interactions which were undertaken in the laboratory.

\section{References}

Arancibia, C., Jublot, L., Costell, E., \& Bayarri, S. (2011). Flavor release and sensory characteristics of o/w emulsions. Influence of composition, microstructure and rheological behavior. Food Research International, 44, 1632-1641.

Arvisenet, G., Le Bail, P., Voilley, A., \& Cayot, N. (2002). Influence of physicochemical interactions between amylose and aroma compounds on the retention of aroma in food-like matrices. Journal of Agricultural and Food Chemistry, 50, 7088-7093.

Auvray, M., \& Spence, C. (2008). The multisensory perception of flavour. Consciousness and Cognition, 17, 1016-1031.

Baek, I., Linforth, R. S. T., Blake, A., \& Taylor, A. J. (1999). Sensory perception is related to the rate of change of volatile concentration in-nose during eating of model gels. Chemical Senses, 24, 155-160.

Biasioli, F., Gasperi, F., Aprea, E., Endrizzi, I., Framondino, V., Marini, F., et al. (2006). Correlation of PTR-MS spectral fingerprints with sensory characterisation of flavour and odour profile of "Trentingrana" cheese. Food Quality and Preference, $17,63-75$.

Blake, R. S., Monks, P. S., \& Ellis, A. M. (2009). Proton-Transfer Reaction Mass Spectrometry. Chemical Reviews, 109, 861-896.

Boakes, R. A., \& Hemberger, H. (2012). Odour-modulation of taste ratings by chefs. Food Quality and Preference, 25, 81-86.

Boland, A. B., Delahunty, C. M., \& van Ruth, S. M. (2006). Influence of the texture of gelatin gels and pectin gels on strawberry flavour release and perception. Food Chemistry, 96, 452-460.

Buettner, A., \& Beauchamp, J. (2010). Chemical input - sensory output: Diverse modes of physiology-flavour interaction. Food Quality and Preference, 21, 915-924.

Buettner, A., Beer, A., Hannig, C., Settles, M., \& Schieberle, P. (2002). Physiological and analytical studies on flavor perception dynamics as induced by the eating and swallowing process. Food Quality and Preference, 13, 497-504.

Bult, J. H. F., de Wijk, R. A., \& Hummel, T. (2007). Investigations on multimodal sensory integration: Texture, taste, and ortho- and retronasal olfactory stimuli in concert. Neuroscience Letters, 411, 6-10.

Burseg, K. M. M., Camacho, S., Knoop, J., \& Bult, J. H. F. (2010). Sweet taste intensity is enhanced by temporal fluctuation of aroma and taste, and depends on phase shift. Physiology and Behavior, 101, 726-730.

Burseg, K. M. M., \& de Jong, C. (2009). Application of the Olfactoscan method to study the ability of saturated aldehydes in masking the odor of methional. Journal of Agricultural and Food Chemistry, 57, 9086-9090.

Clark, C. C., \& Lawless, H. T. (1994). Limiting response alternatives in time-intensity scaling: An examination of the halo-dumping effect. Chemical Senses, 19, 583-594.

Déléris, I., Saint-Eve, A., Dakowski, F., Sémon, E., Le Quéré, J. L., Guillemin, H., et al. (2011). The dynamics of aroma release during consumption of candies of different structures, and relationship with temporal perception. Food Chemistry, 127, 1615-1624.

Delwiche, J. (2004). The impact of perceptual interactions on perceived flavor. Food Quality and Preference, 15, 137-146. 
Dijksterhuis, G. B., \& Piggott, J. R. (2001). Dynamic methods of sensory analysis. Trends in Food Science and Technology, 11, 284-290.

Ferry, A. L., Hort, J., Mitchell, J. R., Cook, D. J., Lagarrigue, S., \& Valles-Pamies, B. (2006). Viscosity and flavour perception: Why is starch different from hydrocolloids? Food Hydrocolloids, 20, 855-862.

Ferry, A. L., Hort, J., Mitchell, J. R., Lagarrigue, S., \& Valles-Pamies, B. (2004). Effect of amylase activity on starch viscosity and its implications for flavor perception. Journal of Texture Studies, 35, 511-524.

Gierczynski, I., Laboure, H., \& Guichard, E. (2008). In vivo aroma release of milk gels of different hardnesses: Inter-individual differences and their consequences on aroma perception. Journal of Agricultural and Food Chemistry, 56, 1697-1703.

González-Tomás, L., Bayarri, S., Taylor, A. J., \& Costell, E. (2007). Flavour release and perception from model dairy custards. Food Research International, 40, 520-528.

Guinard, J. X., Zoumas-Morse, C., \& Walchak, C. (1998). Relation between parotid saliva flow and composition and the perception of gustatory and trigeminal stimuli in foods. Physiology and Behavior, 63, 109-118.

Guinard, J. X., Zoumas-Morse, C., Walchak, C., \& Simpson, H. (1997). Relation between saliva flow and flavor release from chewing gum. Physiology and Behavior, 61, 591-596.

Hansson, A., Giannouli, P., \& Van Ruth, S. M. (2003). The influence of gel strength on aroma release from pectin gels in a model mouth and in vivo monitored with proton-transfer-reaction mass spectrometry. Journal of Agricultural and Food Chemistry, 51, 4732-4740.

Harvey, B. A., \& Barra, J. (2003). Real time breath and headspace analysis of flavour volatiles. European Journal of Pharmaceutics and Biopharmaceutics, 55, 261-269.

Heenan, S., Soukoulis, C., Silcock, P., Fabris, A., Aprea, E., Cappellin, L., et al. (2012). PTR-TOF-MS monitoring of in vitro and in vivo flavour release in cereal bars with varying sugar composition. Food Chemistry, 131, 477-484.

Hewson, L., Hollowood, T., Chandra, S., \& Hort, J. (2008). Taste-aroma interactions in a citrus flavoured model beverage system: Similarities and differences between acid and sugar type. Food Quality and Preference, 19, 323-334.

Hollowood, T. A., Linforth, R. S. T., \& Taylor, A. J. (2002). The effect of viscosity on the perception of flavour. Chemical Senses, 27, 583-591.

Hort, J., \& Hollowood, T. A. (2004). Controlled continuous flow delivery system for investigating taste-aroma interactions. Journal of Agricultural and Food Chemistry, 52, 4834-4843.

Hummel, T., \& Heilmann, S. (2008). Olfactory event-related potentials in response to ortho- and retronasal stimulation with odors related or unrelated to foods. International Dairy Journal, 18, 874-878.

Juteau, A., Tournier, C., \& Guichard, E. (2004). Influence of type and amount of gelling agent on flavour perception: Physicochemical effect or interaction between senses? Flavour and Fragrance Journal, 19, 483-490.

Keršienė, M., Adams, A., Dubra, A., De Kimpe, N., \& Leskauskaitė, D. (2008) Interactions between flavour release and rheological properties in model custard desserts: Effect of starch concentration and milk fat. Food Chemistry, 108, 1183-1191.

Kühn, J., Delahunty, C. M., Considine, T., \& Singh, H. (2009). In-mouth flavour release from milk proteins. International Dairy Journal, 19, 307-313.

Labbe, D., Damevin, L., Vaccher, C., Morgenegg, C., \& Martin, N. (2006). Modulation of perceived taste by olfaction in familiar and unfamiliar beverages. Food Quality and Preference, 17, 582-589.

Labbe, D., \& Martin, N. (2009). Impact of novel olfactory stimuli at supra and subthreshold concentrations on the perceived sweetness of sucrose after associative learning. Chemical Senses, 34, 645-651.

Labbe, D., Rytz, A., Morgenegg, C., Ali, S., \& Martin, N. (2007). Subthreshold olfactory stimulation can enhance sweetness. Chemical Senses, 32, 205-214.

Lawrence, G., Salles, C., Palicki, O., Septier, C., Busch, J., \& Thomas-Danguin, T. (2011). Using cross-modal interactions to counterbalance salt reduction in solid foods. International Dairy Journal, 21, 103-110.

Lawrence, G., Salles, C., Septier, C., Busch, J., \& Thomas-Danguin, T. (2009). Odourtaste interactions: A way to enhance saltiness in low-salt content solutions. Food Quality and Preference, 20, 241-248.

Lee, W. E., \& Pangborn, R. M. (1986). Time-intensity: The temporal aspects of sensory perception. Food Technology, 40, 71-78.

Lethuaut, L., Brossard, C., Meynier, A., Rousseau, F., Llamas, G., Bousseau, B., et al. (2005). Sweetness and aroma perceptions in dairy desserts varying in sucrose and aroma levels and in textural agent. International Dairy Journal, 15, 485-493.

Lethuaut, L., Weel, K. G. C., Boelrijk, A. E. M., \& Brossard, C. (2004). Flavor perception and aroma release from model dairy desserts. Journal of Agricultural and Food Chemistry, 52, 3478-3485.

Lindinger, W., Hansel, A., \& Jordan, A. (1998). On-line monitoring of volatile organic compounds at pptv levels by means of proton-transfer-reaction mass spectrometry (PTR-MS) medical applications, food control and environmental research. International Journal of Mass Spectrometry and Ion Processes, 173, 191-241.

Linforth, R. S. T., Ingham, K. E., \& Taylor, A. J. (1996). Time course profiling of volatile release from foods during the eating process. In A. J. Taylor \& D. S. Mottram (Eds.), Flavor Science: Recent Developments (pp. 361-368). London: Royal Society of Chemistry.

Marks, L. E., Shepard, T. G., Burger, K., \& Chakwin, E. M. (2012). Flavor-intensity perception: Effects of stimulus context. Physiology and Behavior, 105, 443-450.

Mei, J. B., Reineccius, G. A., Knighton, W. B., \& Grimsrud, E. P. (2004). Influence of strawberry yogurt composition on aroma release. Journal of Agricultural and Food Chemistry, 52, 6267-6270.

Mestres, M., Kieffer, R., \& Buettner, A. (2006). Release and perception of ethyl butanoate during and after consumption of whey protein gels: Relation between textural and physiological parameters. Journal of Agricultural and Food Chemistry, 54, 1814-1821.

Mestres, M., Moran, N., Jordan, A., \& Buettner, A. (2005). Aroma release and retronasal perception during and after consumption of flavored whey protein gels with different textures. 1. In vivo release analysis. Journal of Agricultural and Food Chemistry, 53, 403-409.

Morris, C., Labarre, C., Koliandris, A. L., Hewson, L., Wolf, B., Taylor, A. J., et al. (2010) Effect of pulsed delivery and bouillon base on saltiness and bitterness perceptions of salt delivery profiles partially substituted with $\mathrm{KCl}$. Food Quality and Preference, 21, 489-494.

Murphy, C., \& Cain, W. S. (1980). Taste and olfaction: Independence vs. interaction. Physiology and Behavior, 24, 601-605.

Nasri, N., Beno, N., Septier, C., Salles, C., \& Thomas-Danguin, T. (2011). Cross-modal interactions between taste and smell: Odour-induced saltiness enhancement depends on salt level. Food Quality and Preference, 22, 678-682.

Noble, A. C. (1996). Taste-aroma interactions. Trends in Food Science and Technology, 7, 439-443.

Overbosch, P. (1986). A theoretical model for perceived intensity in human taste and smell as a function of time. Chemical Senses, 11, 315-329.

Pineau, N., Goupil de Bouille, A., Lepage, M., Schlich, P., Martin, N., \& Rytz, A. (2012). Temporal dominance of sensations: What is a good attribute list? Food Quality and Preference, 26, 159-165.

Pineau, N., Pessina, R., Cordelle, S., Imbert, A., Rogeaux, M., \& Schlich, P. (2004). Temporal dominance of sensations: Comparison with conventional profiling and time intensity. In Sensometrics Conference, Oral Presentation.

Pineau, N., Schlich, P., Cordelle, S., Mathonnière, C., Issanchou, S., Imbert, A., et al. (2009). Temporal dominance of sensations: Construction of the TDS curves and comparison with time-intensity. Food Quality and Preference, 20, 450-455.

Poinot, P., Arvisenet, G., Texier, F., Lethuaut, L., Mehinagic, E., Vigneau, E., et al. (2011). Use of sense masking to study sensory modalities singly: Interest for the understanding of apple in-mouth perception. Food Quality and Preference, 22, 573-580.

Rolls, E. T. (2005). Taste, olfactory, and food texture processing in the brain, and the control of food intake. Physiology and Behavior, 85, 45-56.

Roudnitzky, N., Bult, J. H. F., de Wijk, R. A., Reden, J., Schuster, B., \& Hummel, T. (2011). Investigation of interactions between texture and ortho- and retronasal olfactory stimuli using psychophysical and electrophysiological approaches. Behavioural Brain Research, 216, 109-115.

Saint-Eve, A., Déléris, I., Panouillé, M., Dakowski, F., Cordelle, S., Schlich, P., et al. (2011). How texture influences aroma and taste perception over time in candies. Chemosensory Perception, 4, 32-41.

Saint-Eve, A., Lauverjat, C., Magnan, C., Déléris, I., \& Souchon, I. (2009). Reducing salt and fat content: Impact of composition, texture and cognitive interactions on the perception of flavoured model cheeses. Food Chemistry, 116, 167-175.

Saint-Eve, A., Paci Kora, E., \& Martin, N. (2004). Impact of the olfactory quality and chemical complexity of the flavouring agent on the texture of low fat stirred yogurts assessed by three different sensory methodologies. Food Quality and Preference, 15, 655-668.

Saenz-Navajas, M. P., Campo, E., Avizcuri, J. M., Valentin, D., Fernandez-Zurbano, P., \& Ferreira, V. (2012). Contribution of non-volatile and aroma fractions to in mouth sensory properties of red wines: Wine reconstitution strategies and sensory sorting task. Analytica Chimica Acta, 732, 64-72.

Sáenz-Navajas, M. P., Campo, E., Fernández-Zurbano, P., Valentin, D., \& Ferreira, V. (2010). An assessment of the effects of wine volatiles on the perception of taste and astringency in wine. Food Chemistry, 121, 1139-1149.

Schifferstein, H. N. J., \& Verlegh, P. W. J. (1996). The role of congruency and pleasantness in odor-induced taste enhancement. Acta Psychologica, 94, 87-105.

Siefarth, C., Tyapkova, O., Beauchamp, J., Schweiggert, U., Buettner, A., \& Bader, S. (2011). Mixture design approach as a tool to study in vitro flavor release and viscosity interactions in sugar-free polyol and bulking agent solutions. Food Research International, 44, 3202-3211.

Stevenson, R. J., Prescott, J., \& Boakes, R. A. (1999). Confusing tastes and smells: How odours can influence the perception of sweet and sour tastes. Chemical Senses, 24, 627-635.

Taylor, A. J., Linforth, R. S. T., Harvey, B. A., \& Blake, A. (2000). Atmospheric pressure chemical ionisation mass spectrometry for in vivo analysis of volatile flavour release. Food Chemistry, 71, 327-338.

Tournier, C., Sulmont-Rossé, C., Sémon, E., Vignon, A., Issanchou, S., \& Guichard, E. (2009). A study on texture-taste-aroma interactions: Physico-chemical and cognitive mechanisms. International Dairy Journal, 19, 450-458.

Ventanas, S., Mustonen, S., Puolanne, E., \& Tuorila, H. (2010a). Odour and flavour perception in flavoured model systems: Influence of sodium chloride, umami compounds and serving temperature. Food Quality and Preference, 21, 453-462.

Ventanas, S., Puolanne, E., \& Tuorila, H. (2010b). Temporal changes of flavour and texture in cooked bologna type sausages as affected by fat and salt content Meat Science, 85, 410-419.

Weel, K. G. C., Boelrijk, A. E. M., Alting, A. C., van Mil, P. J. J. M., Burger, J. J., Gruppen, H., et al. (2002). Flavor release and perception of flavored whey protein gels: Perception is determined by texture rather than by release. Journal of Agricultural and Food Chemistry, 50, 5149-5155.

Welge-Lüssen, A., Husner, A., Wolfensberger, M., \& Hummel, T. (2009). Influence of simultaneous gustatory stimuli on orthonasal and retronasal olfaction. Neuroscience Letters, 454, 124-128.

Zafeiropoulou, T., Evageliou, V., Gardeli, C., Yanniotis, S., \& Komaitis, M. (2012). Retention of selected aroma compounds by gelatine matrices. Food Hydrocolloids, 28, 105-109. 